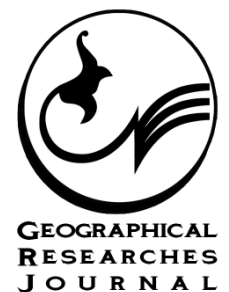

\title{
Effect of Environmental and Geographical Factors on Distribution of the Chalcolithic Sites in the Hourand Region, Iran
}

\section{ART I CLE INF O}

\section{Article Type}

Original Research

\section{Authors}

Bakhtiari S. ${ }^{1} P h D$,

Shirazi R. ${ }^{* 1} P h D$

Omrani B. ${ }^{2} P h D$,

Bakhtiari S. ${ }^{3} P h D$,

Salmanpour R. ${ }^{4} M A$

Abtahi Foroushani SZ. ${ }^{4} M A$

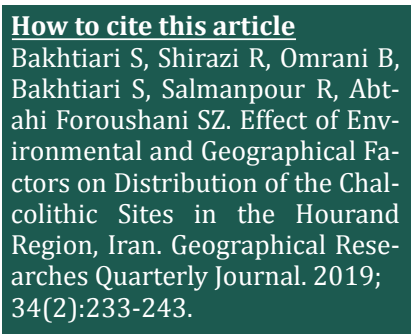

${ }^{1}$ Department of Archaeology, Faculty of Literature and Human Sciences, University of Sistan and Baluchestan, Zahedan, Iran

${ }^{2}$ Department of Prehistory, Iranian Center for Archaeological Research, Research Institute for Cultural Heritage and Tourism, Tehran, Iran

${ }^{3}$ Department of Archaeology, Faculty of Art \& Architecture, University of Mazandaran, Sari, Iran ${ }^{4}$ Department of Archaeology, Faculty of Literature \& Human Sciences, Tehran University, Tehran, Iran

\section{*Correspondence}

Address: Iranian Center for Archaeological Research, Research Institute for Cultural Heritage and Tourism, Second Building of National Museum of Iran, No. 1, Prof. Rolan Street, First of 30-Tir Street, Emam Khomeini Avenue, Tehran, Iran. Post Box: 11365-4364

Phone: +98 (21) 66701747

Fax: +98 (21) 66752736

rouhollah.shirazi@lihu.usb.ac.ir

\section{Article History}

Received: June 26, 2018

Accepted: March 12, 2019

ePublished: June 20, 2019

\begin{abstract}
A B S T R A C T
Aims \& Backgrounds Ancient sites of chalcolithic age in the Hourand region located at the eastern part of Azerbaijan, Iran covers the historical period from the late 6th millennium to the 4th millennium BC. This study aimed to investigate the effect of environmental and geographical factors on the distribution of the chalcolithic sites in the Hourand region located at the eastern part of Azerbaijan, Iran.

Methodology The proposed models for investigating the site selection and distribution of the ancient sites in the Hourand region was based on the ArcGIS software, multivariable statistics method, and digital spatial data. By use of this model, the environmental and cultural factors that had a greater role in shaping the patterns of spatial data distribution and archaeological sites were analyzed.

Findings The placement position of chalcolithic sites in terms of distance to water resources and communication paths and degree of the slope were classified into 5, 6 and 6 categories, respectively. Conclusion The placement position of ancient sites of the Hourand region in chalcolithic age is a function of natural components includes water resources, communication paths and elevation from the sea level and the other factors have had little influence on the site selection.
\end{abstract}

Keywords Hourand; Chalcolithic; Settlement Pattern; Environmental Factors; Spatial Distribution

\section{I T A T I O N L I N K S}

[Ajorlou; 2013] The Palaeo-climate of Iranian Plateau in the Neolithic age; [Bahrami Nia, et al; 2014] Analysis of the role of environmental factors in the spatial distribution of the Neolithic and Chalcolithic sites of Ardal county, Chaharmahal Va Bakhtiari province; [Bottema;1986] A late quaternary pollen diagram from Lake Urmia, northwestern Iran; [Djamali, et al; 2008] A late Pleistocene long pollen record from Lake Urmia, NW Iran; [Djamali, et al; 2009] A late Holocene pollen record from lake Almalou in northwest Iran: Evidence for changing land use in relation to some historical events during the last 3700 years; [Dousti;1994] The history and geography of Arasbaran; [El-Moslimany;1987] The late Pleistocene climates of the lake Zeribar region (Kurdistan, western Iran) deduced from the ecology and pollen production of no arboreal vegetation; [Farhoudi;1990] Atlas of Iran slope \& its grounding results. Geographical Research; [Khamachi;1991] Geography of east Azarbaijan; [Kowalewski;2003] Regional settlement pattern studies; [Maziar; 2015] Settlement dynamics of the Kura-Araxes culture: An overview of the late Chalcolithic \& early Bronze age in the Khoda Afarin plain, NW Iran; [Motarjem; 2008] An investigation \& analysis of the patterns of the establishment of the Bronze age in the plains around the Alvand Mountains, Hamadan [Dissertation]; [Almasi; 2014] An investigation of the cultural changes of Kangavar plain from the Chalcolithic to the late Bronze age according to the settlement models; [Niknami, et al; 2007] Theories \& techniques of prediction modeling (estimation) of settlements \& distributions of prehistoric sites in archaeological landscapes by using GIS \& regression software, a case study: Gamasiab basin, Central Zagros; [Nikzad, et al; 2010] Investigating patterns of the Neolithic period in Sar-Firoozabad plain, Kermanshah; [Omidvar; 2015] An introduction to soil conservation \& watershed; [Ozdogan;1999] Neolithic in Turkey: The cradle of civilization: New discoveries (Ancient Anatolian civilizations series); [Salmanpour \& Abtahi Froushani;2013] Final report on the archaeological survey of Horand region; [Shahrabi \& Kelts; 1986] Holocene sedimentology of hypersaline lake Uremia, northwestern Iran; [Van Zeist \& Bottema;1991] Late Quaternary vegetation of the near east; [Van Zeist \& Wright; 1963] Preliminary pollen studies at lake Zeribar, Zagros mountains, southwestern Iran; [Velayati \& Khanali; 2017] Analyzing settlement patterns of Bronze age sites at Bostan Abad, according to regional archaeological survey 
باستانشناختى را در توزيع و گسترش، تحت تأثير قرار مىدادند؛

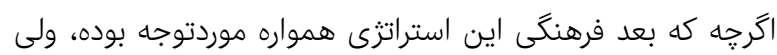

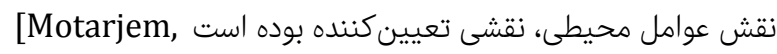

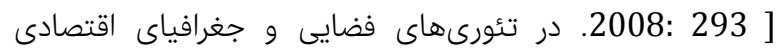
الكوهاى استقرارى به دو ويزَّى بنيادى توجه دارند. اولين ويزَّى

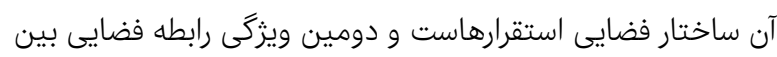

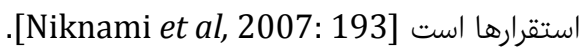

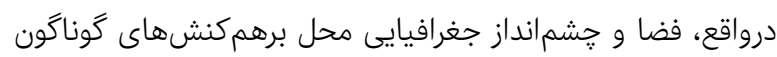

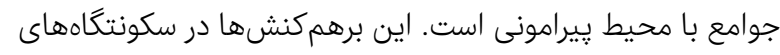

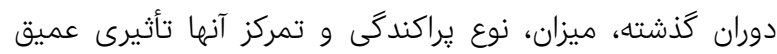

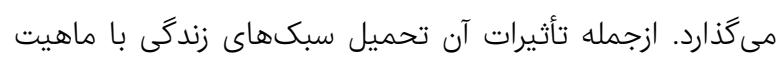

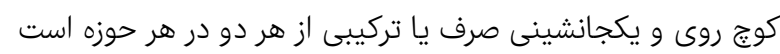

.[Bahraminia et al, 2014] باستانشناسى بلعنوان نظامى علمى براى يردازش مدلها و وايجاد

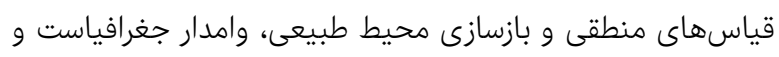

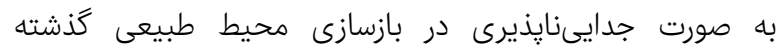

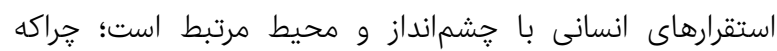

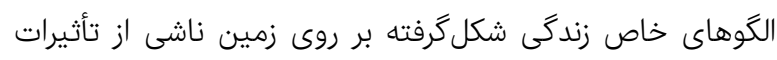

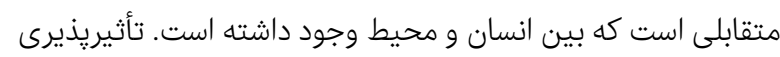

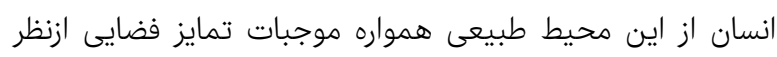

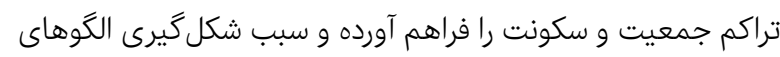

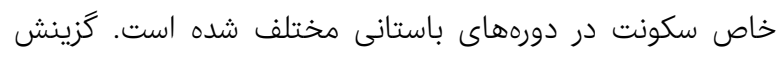

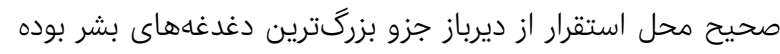

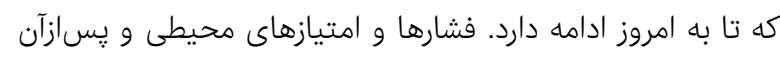

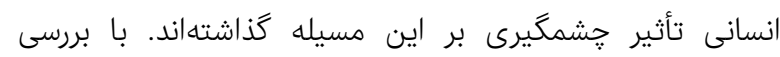

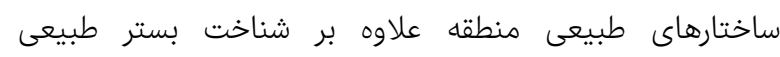

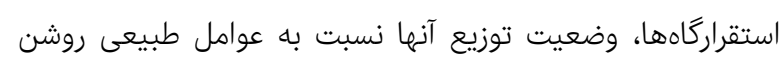

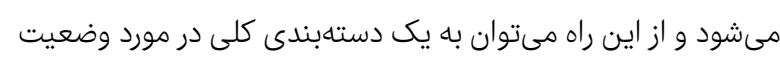

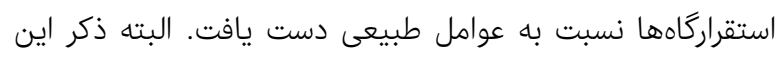

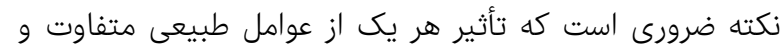

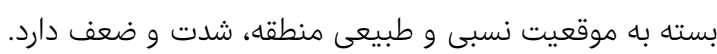

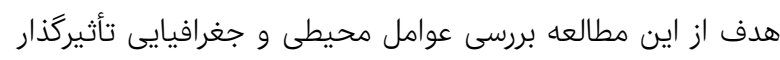

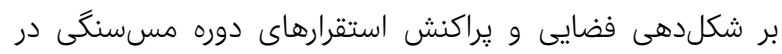
منطقه هوراند بود.

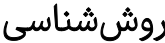

يزوهش حاضر با روش توصيفى تحليلى و براساس ساختارهاى

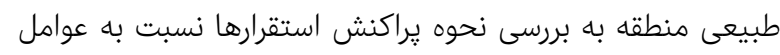

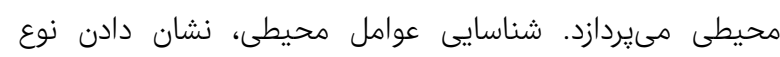

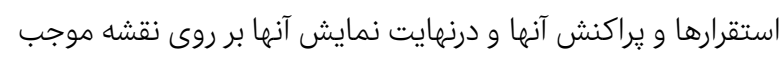

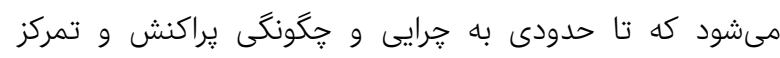

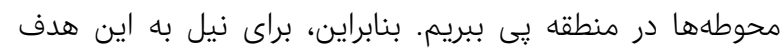

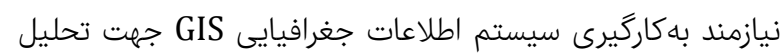

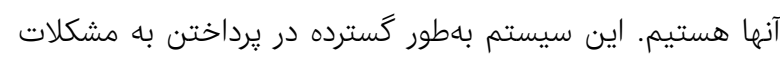

تاثير عوامل محيطى و جغرافيايى بر يراكنش استقرارهاى مسسنگى در حوزه هوراند

سحر بختيارى PhD كروه باستانشناسى، دانشكده ادبيات و علوم انسانى، دانشكاه سيستان و إناري

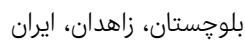

PhD روحاله شيرازى

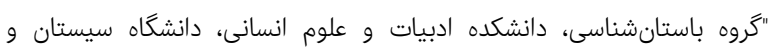

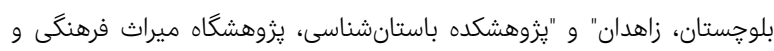

كردشكرى، تهران"، ايران

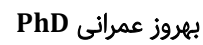

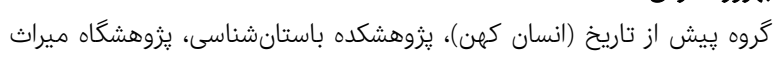
فرهنكى و كردشكَرى، تهران، ايران

سييده بختيارى PhD

كروه باستانشناسى، دانشكده هنر و معمارى، دانشگاه مازندران، سارى، ايران

MA رضا سلمانيور

گروه باستانشناسى، دانشكده ادبيات و علوم انسانى، دانشكاه تهران، تهران، ايران

MA سيده زهرا ابطحى فروشانى

گَروه باستانشناسى، دانشكده ادبيات و علوم انسانى، دانشكاه تهران، تهران، ايران

جكيده اهداف و زمينهها: محوطههاى باستانى دوره مسسنكى در منطقة هوراند در شرق

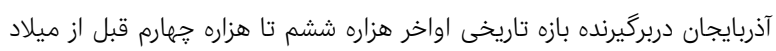

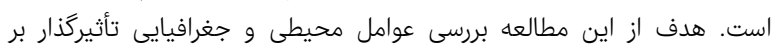

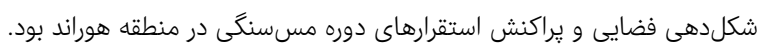

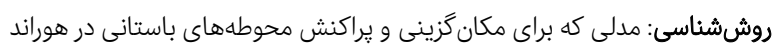

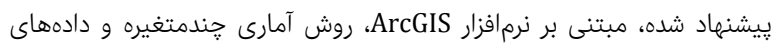

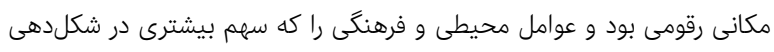

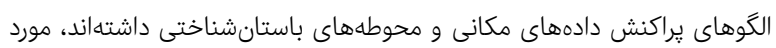

تجزيه و تحليل قرار داد.

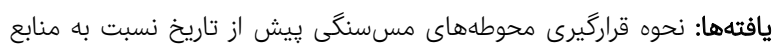

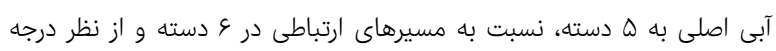

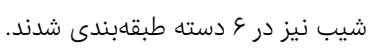

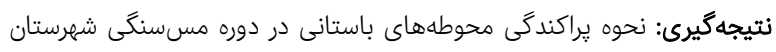

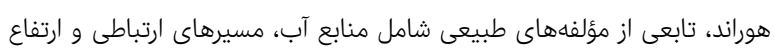

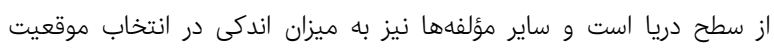
محوطهها تأثير داشتهاند. كليدوارهها: هوراند، مسسنَّ، الكَّى استقرار، عوامل محيطى، توزيع مكانى و فضايى

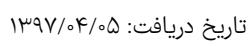

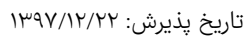
rouhollah.shirazi@lihu.usb.ac.ir :تويسنده مسئوش:

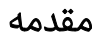

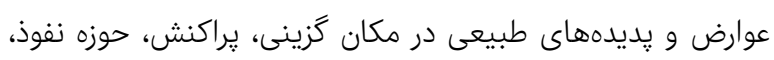

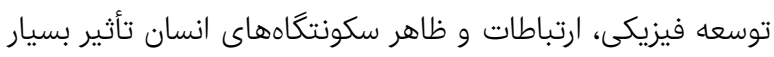

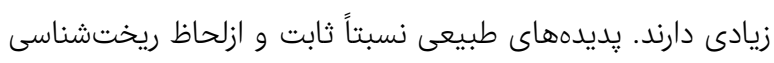

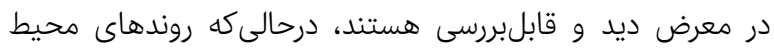

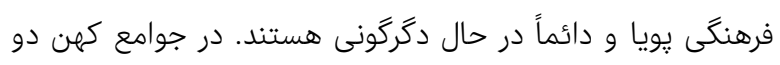

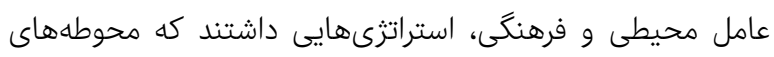




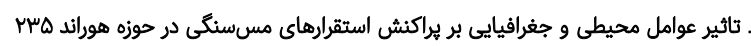

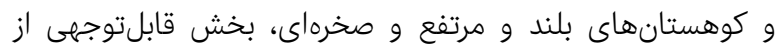

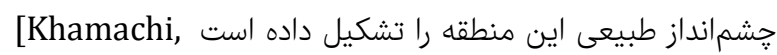

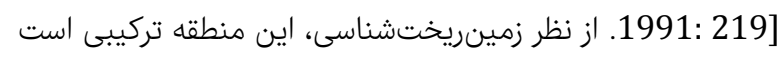

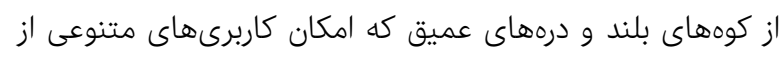

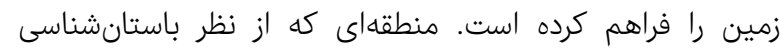

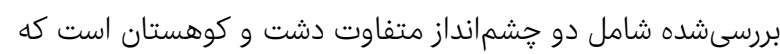

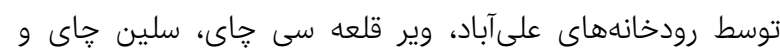

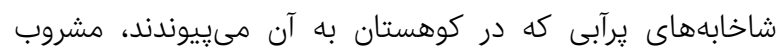

مىشود.

الخوى استقرارى محوطههاى دوره مس سنگ شهرستان هوراند

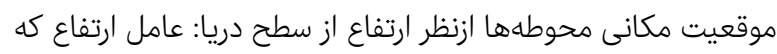

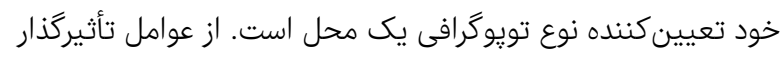

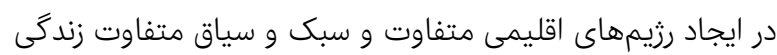

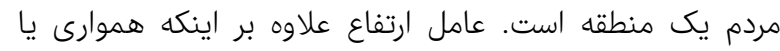

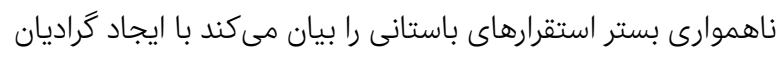

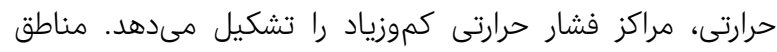

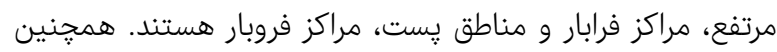

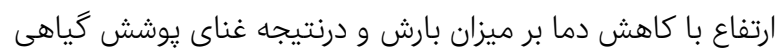

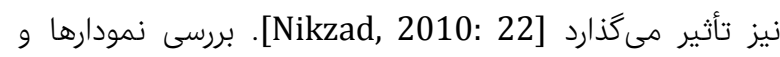

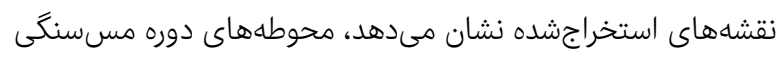

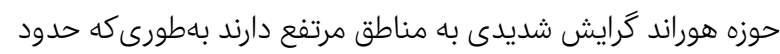

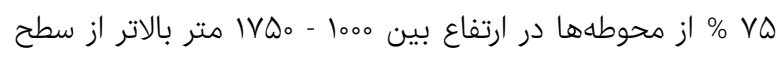

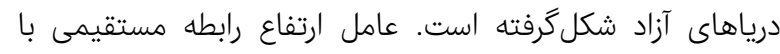

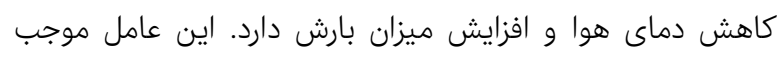

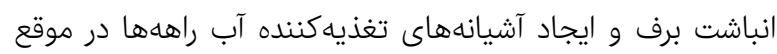

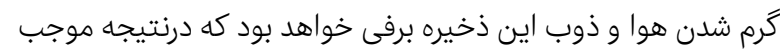

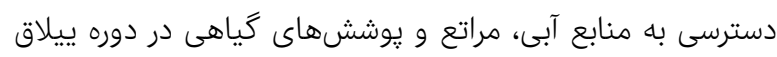
عشاير مىشود.

بهمنظور بررسى نحوه توزيع محوطههاى ييشازتاريخ در رابطه با

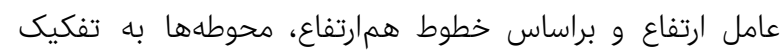

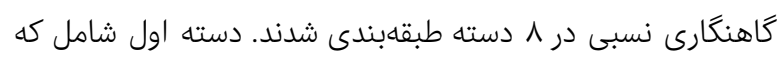

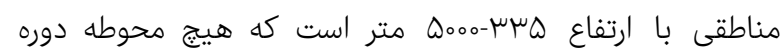

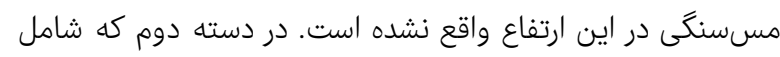

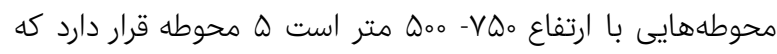

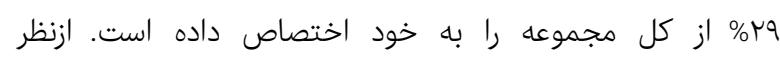

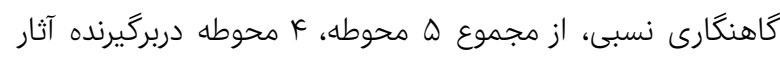

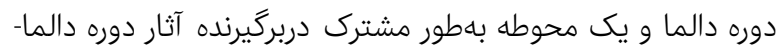

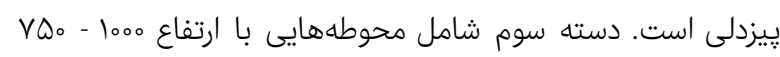

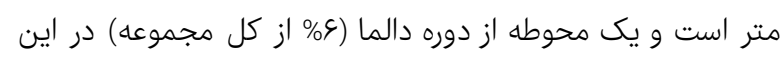

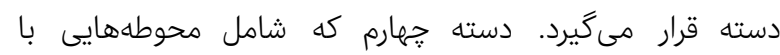

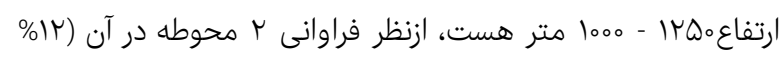
از كل مجموعه) وجود دارد. يك محوطه دربرگيرنده آثار دوره دالما-

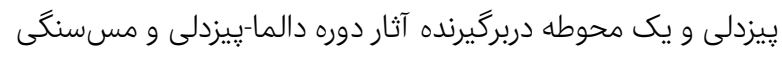

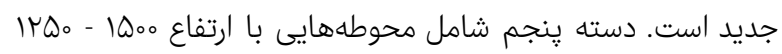

״يجֶيده مربوط به موقعيت و پِراكندگى كاربرد دارد. در اينجا، نقشهها،

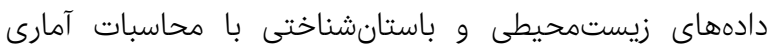

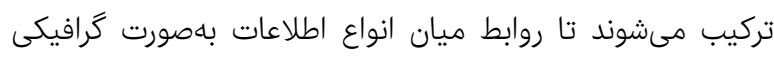

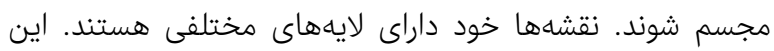

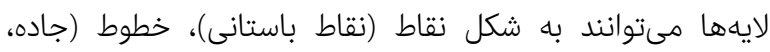

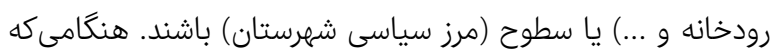

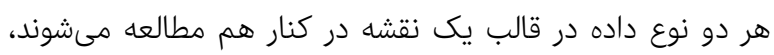

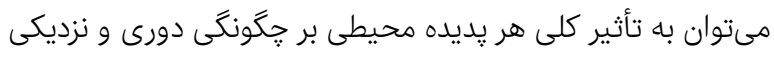

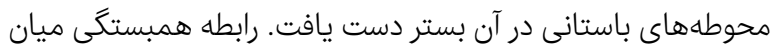

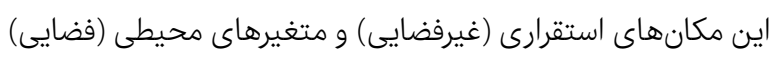

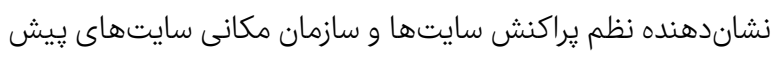
از تاريخ در يهندشتهاست [Niknami et al, 2007]. تقسيمات كشورى يديدهاى امروزى هستند كه مرتب در در حال

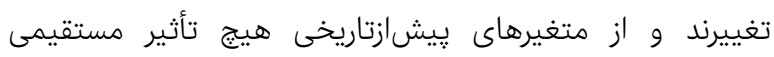

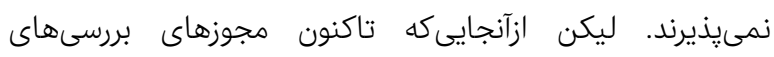

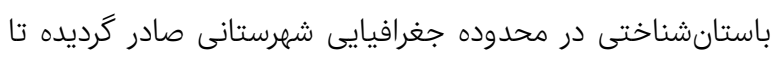

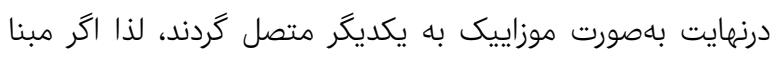

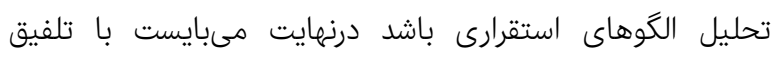

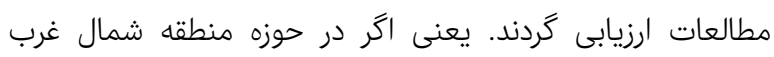

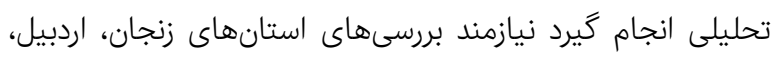

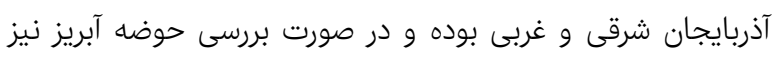

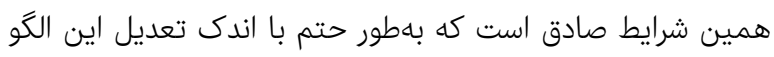

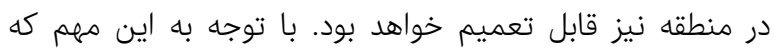

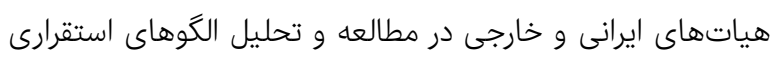

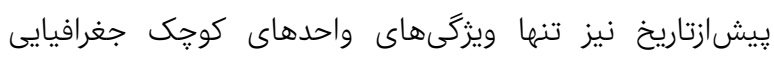
(تقسيمات كشورى امروزى) را بدون توجه به ساير مناطق ييرامون

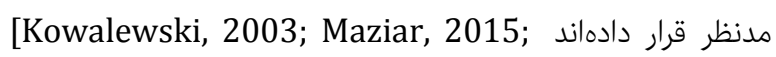

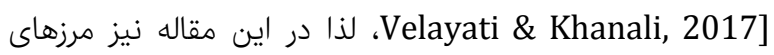

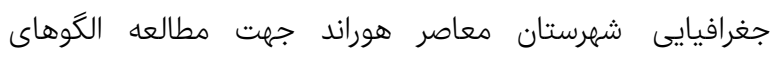

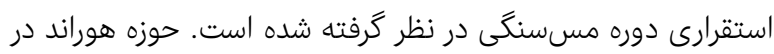

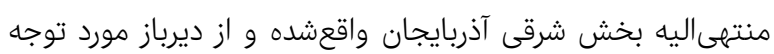
كروههاى انسانى بىشمارى بوده است. جشمانداز زيستمحيطى منطقه

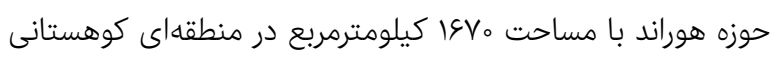
قرارگرفته است و از لحاظ موقعيت سياسى از شمال و غرب به كلي هليبر،

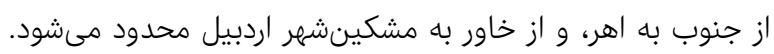

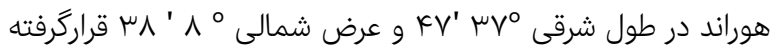

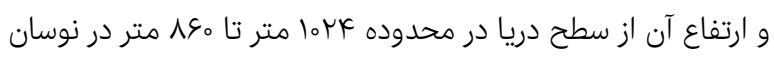

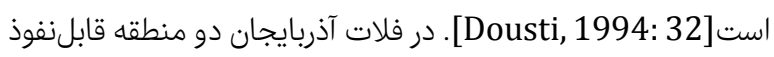
وجود دارد كه نخستين آنها دشت جالدران در شمال غرب آذربايجان و ديكرى دشت مغان است كه در شمال شرق آذربايجان قرارگرفته است [Khamachi, 1991:38]. حوزه هوراند در بخش مرتفع قره

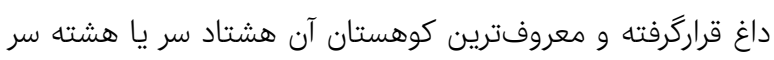

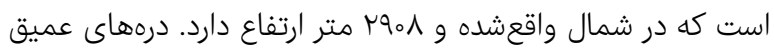


موقعيت مكانى محوطهها ازنظر نوع اقليم

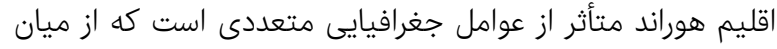
آنها سه عامل كوه، باد و بارش بسيار برجستهاند. آبوهواى آنائ

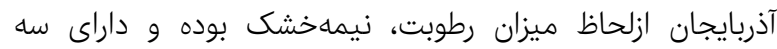
ناحيه متمايز سرد، معتدل و گرم است. كوهستانى بودن آذربايجان

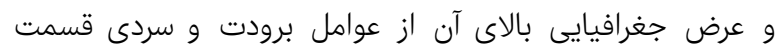
اعظم آن است و كم ارتفاع بودن و اثرات ملايم كننده بخارهاى باى

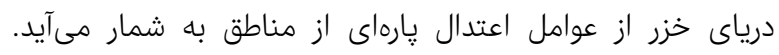

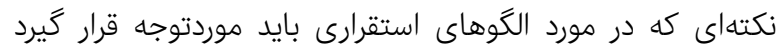

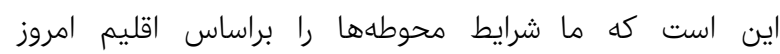

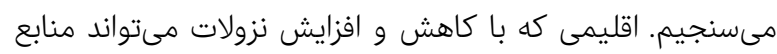
آبى را تحت تأثير قرار دهد و ممكن است درئ در دورهاى به دليل

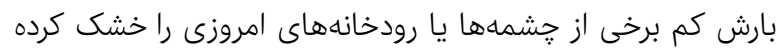

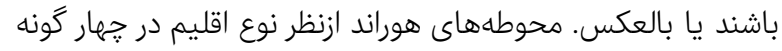

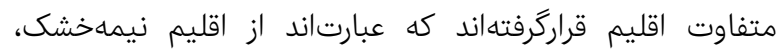
مديترانهاى، نيمه مرطوب و مرطوب. يراكندگى اين محوطهها به

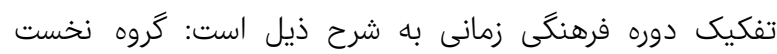

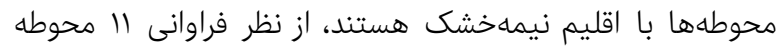

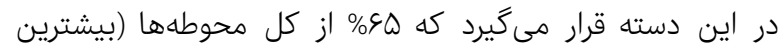

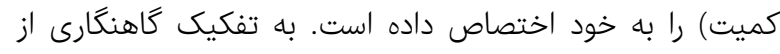

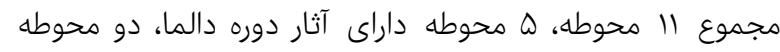

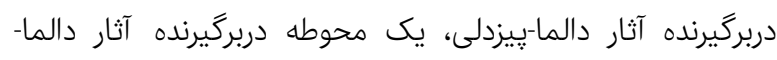

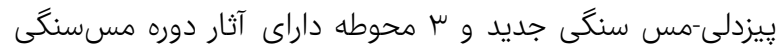
جديد است. دسته دوم شامل محوطههايى هستند كه در اقليم

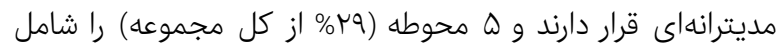

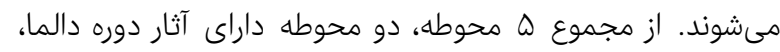

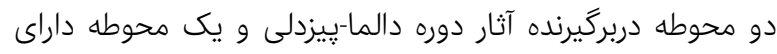

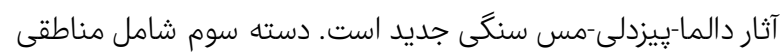

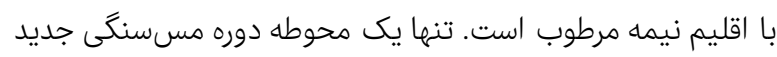

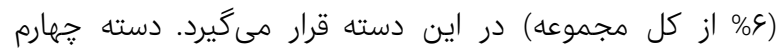

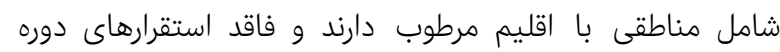
مسسنكى است.

موقعيت مكانى محوطهها از نظر فاصله از منابع آبهاى سطحى اسى

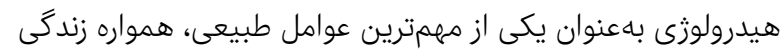

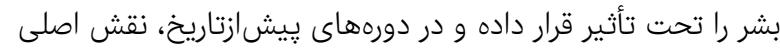
را در شكوفايى و استمرار حيات جوامع انسانى ايفا نموده است.

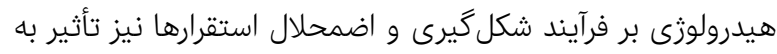
سزايى داشته است. در نتيجأ بررسى باستانشناختى شهرستان هوراند كه در سال بوسرا

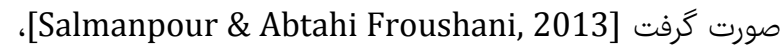
وحوطه دوره مسسنگى از سه دهستان ديكله، دودانگه و

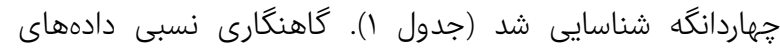

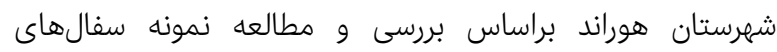
برداشتشده از سطح محوطهها و قياس آنها با نمونهان براس

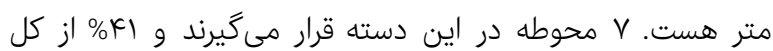

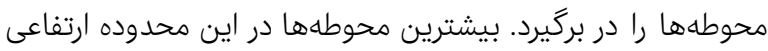

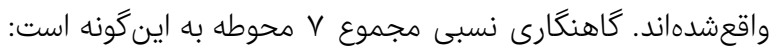

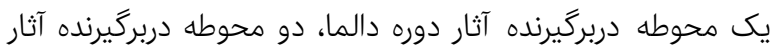

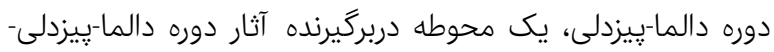

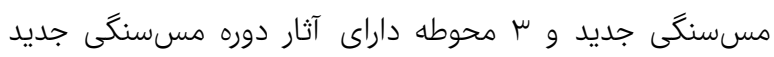

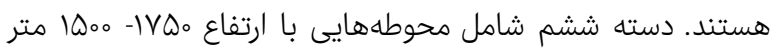

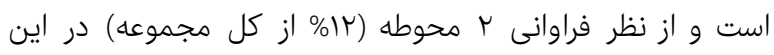

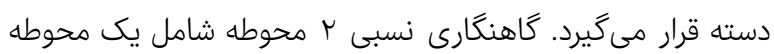

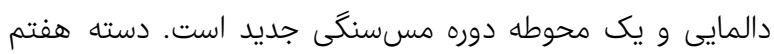

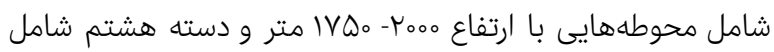

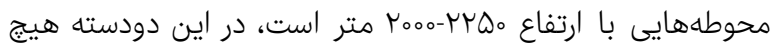
استقرار دوره مسسنكى واقع نشده است. درباره توزيع استقرارگاهها

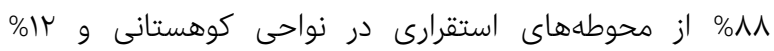

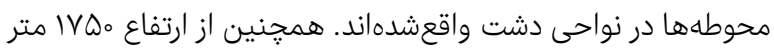

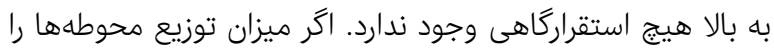

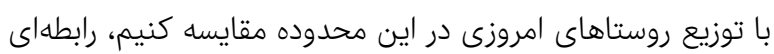

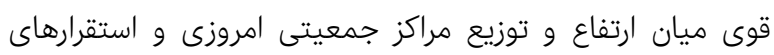

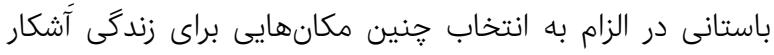

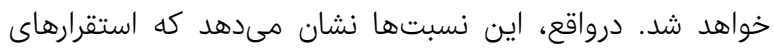

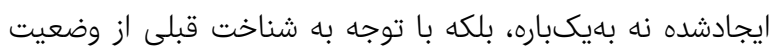

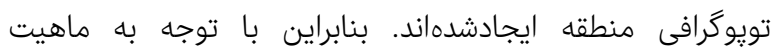

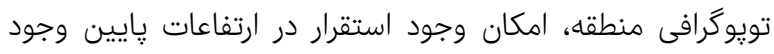

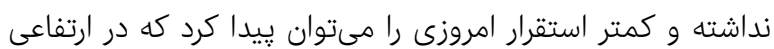
يايينتر از 1000 متر باشد (شكل ()).

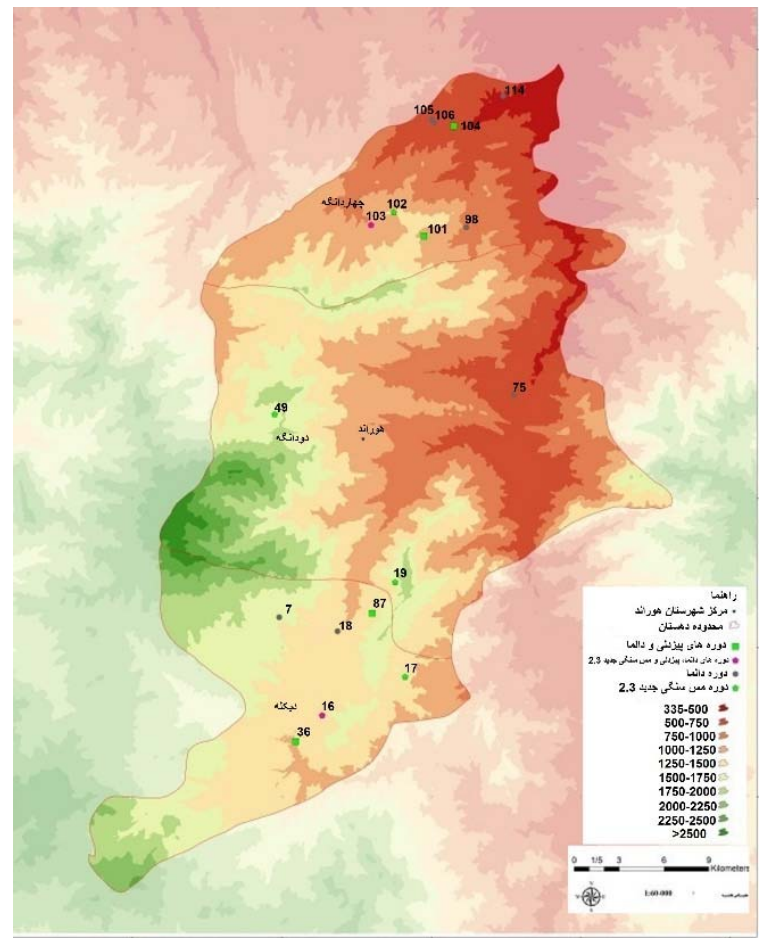

شكل 1) موقعيت محوطههاى دوره مسسنكى هوراند نسبت به ارتفاع از سطح 


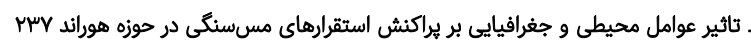

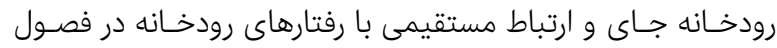
خاص داشته است. براساس شيوه اسكان و به دست نيامدن بقاياى

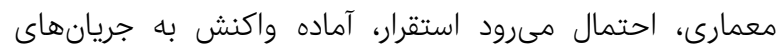

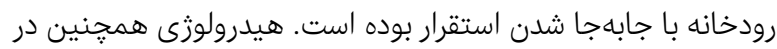

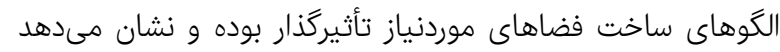

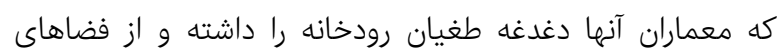
موقتى استفاده كردهاند. نمود باستانشناختى اين قضيه بسترهاى

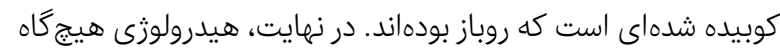

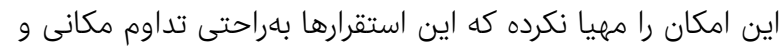

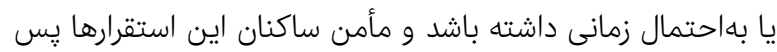
از كذراندن برها زمانى خاص و با تغينمال زمانيرات داشته باش رودخانه تغييريافته است.

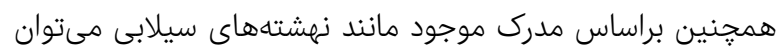

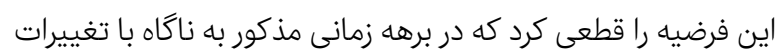

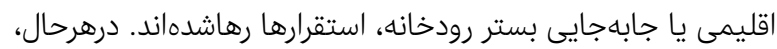

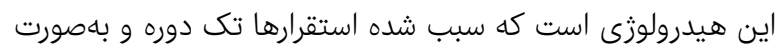

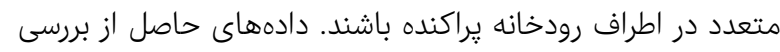

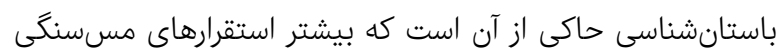

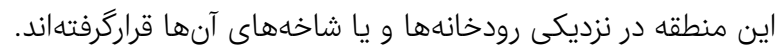

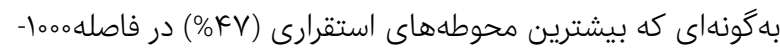

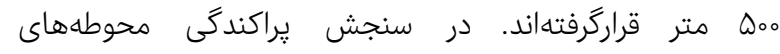

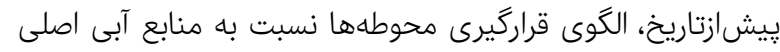

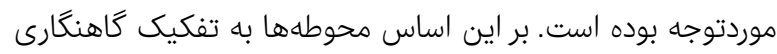

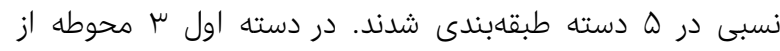

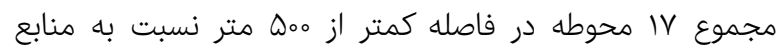

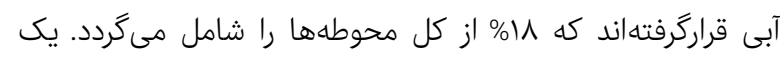
محوطه داراى آثار دوره دالما، يك محوطه دربركيرنده دوره درهان دالما-

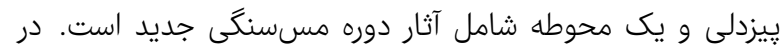

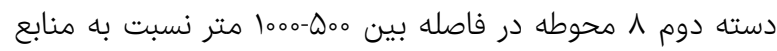

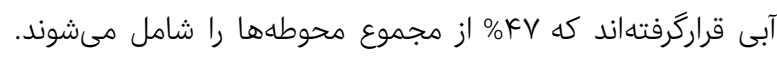

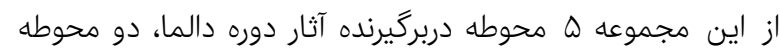

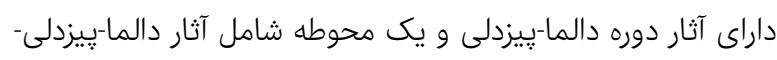

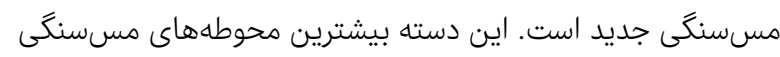

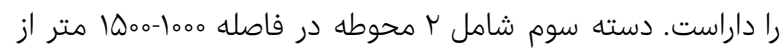

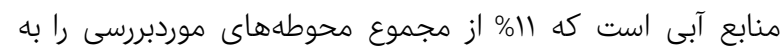

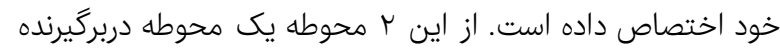

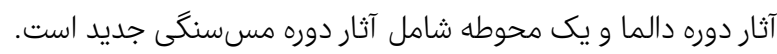

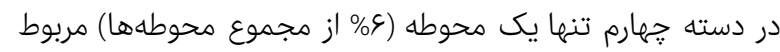

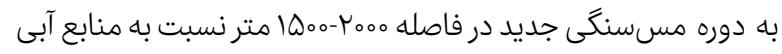

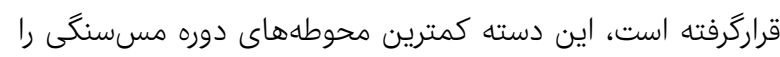

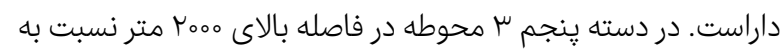

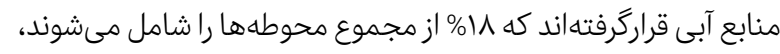

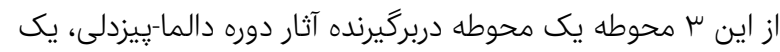

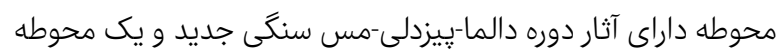

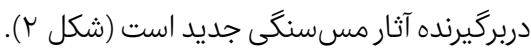

بهدستآمده از لايههاى فرهنگى در كاوشهاى علمى انجامگرفته

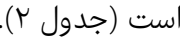

جدول () معرفى محوطههاى مسسنگى حوزه هوراند، آذربايجان شرقى

\begin{tabular}{|c|c|c|c|}
\hline جغرافيايى & دوره فرهنگى & (مترمربع) & نام محوطه \\
\hline ديكله & 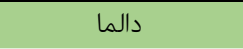 & r $77 \varepsilon$ & كمر قَى لروم \\
\hline ديكله ل & 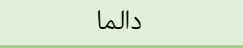 & VIVA。 & كول تيه مورادلو \\
\hline دودانكه & دالما & $\mu_{1}$ & تيه آلا گم وِيق \\
\hline جهاردانكه & 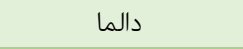 & $1 \pi m q 0$ & كله كوير \\
\hline جهاردانكه & دالما & $1 \varepsilon r \Lambda_{0}$ & آت درسى 1 \\
\hline جهاردانكه & 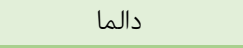 & ر & آت درسى ץ \\
\hline جهاردانكه & 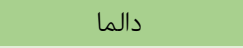 & 0910 & بالالى قايا مميشلى \\
\hline ديكله ل & دالما - يِيزدلى & $|\varepsilon| r \varepsilon$ & نولى ير آيدينلو \\
\hline دودانكه & دالما - بِيزدلى & $\varepsilon \mu_{0} \circ$ & قوبول درسى پيشتو \\
\hline جهاردانكه & دالما - يِيزدلى & MV & كالاوالار ارنان \\
\hline جهاردانكه & دالما - بيزدلى & $\Lambda \mu \Lambda \circ \Lambda$ & شاهليخ صدى بيلى \\
\hline ديكله ل & دالما-هيزدلى-مس سنگى & ErrqAT & حاجىقالاسى (حاجىورد \\
\hline جهاردانكه & دالما-ِيزدلى-مس سنگى & $1 \varepsilon r \Lambda_{0}$ & قميشدى باغ ملالى \\
\hline ديكله ل & مس سنگى جديدسرب & 0.0 & آبل قولى كوفيلى \\
\hline ديكله & مس سنگى جديدسربr & rmvo. & كوهول جيناب \\
\hline دودانكه & مس سنگى جديدسر/ץ & $09 \vee \varepsilon$ & عابدين كندى ميدانلار \\
\hline جهاردانكه & مس سنكى جديدسر/ץ & $r 7 \varepsilon 000$ & ترمه قيران قيه ملالى \\
\hline
\end{tabular}

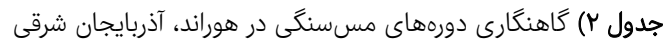

\begin{tabular}{|c|c|c|}
\hline تاريخ & دوره فرهنگى عمومى & دوره فرهنكى منطقه اى \\
\hline 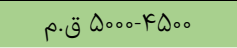 & مس سنگى قديم و ميانه & دالما \\
\hline ق $K Q_{00-K Y_{00}}$ & مس سنگى جديدا & 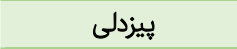 \\
\hline ق $k r_{00-\mu \gamma_{00} / \mu \varepsilon_{00}}$ & مس سنگى جديد //ر & سفال كاه رو (CFW) \\
\hline
\end{tabular}

تحليل اين دادهها در محيط سيستم اطلاعات جغرافيايى انجام

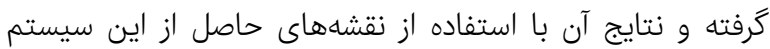

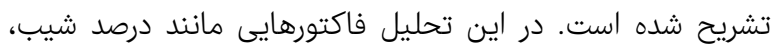

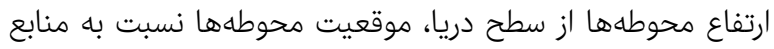

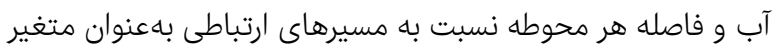
مستقل و وسعت محوطهها بهعنوان متغير وابسته، در نظر

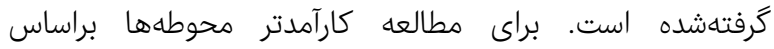

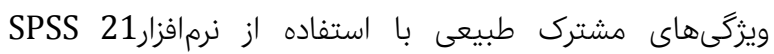

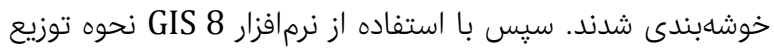

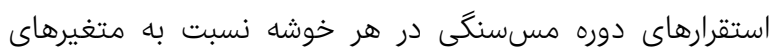
طبيعى مطالعه شد.

\section{يافتهها}

برخى از استقرارهاى هوراند تك دوره و فقط در يك برهه زمانى خاص، مسكونى بوده است. اين استقرارها به فاصله بسيار اندكى از 
خاص محيطى در هر دورهاى بوده است.ب- تراكم استقرارهاى نسبتاً

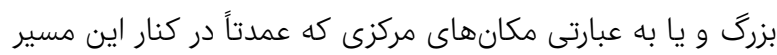

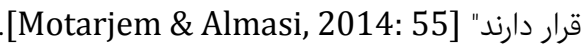

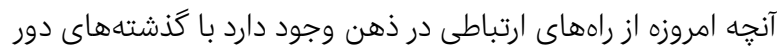

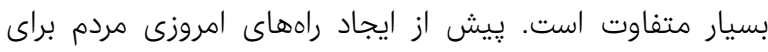

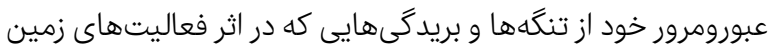

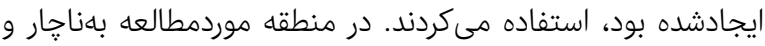

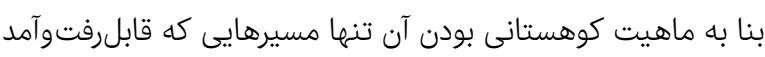

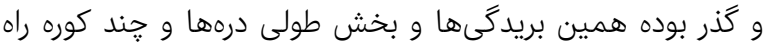

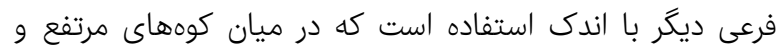

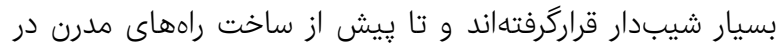

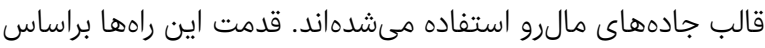

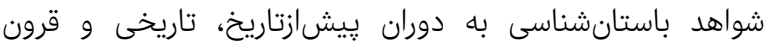

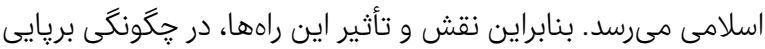

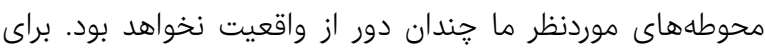

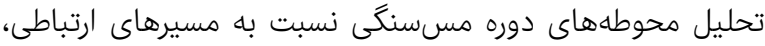

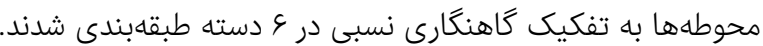

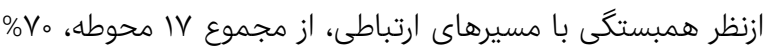

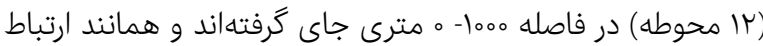

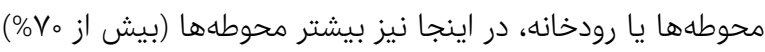
در اين دسته قراركرفتهاند. از اين تعداد 8 محوطه دارئه داراى آثار دوره

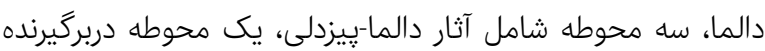

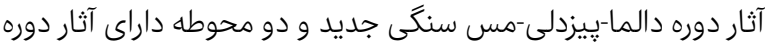

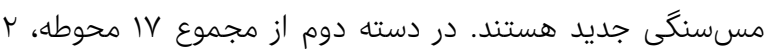

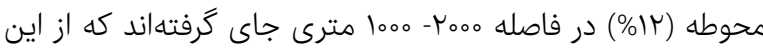

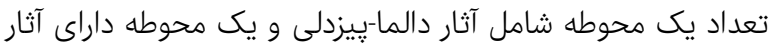

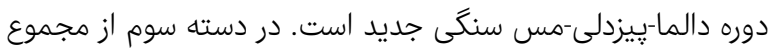

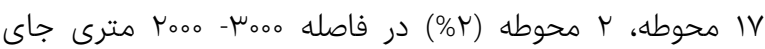

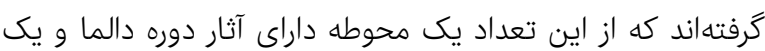

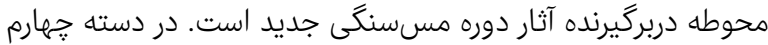

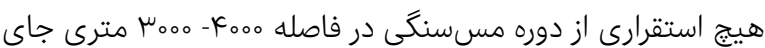

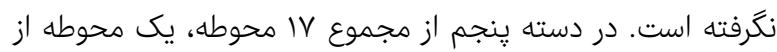

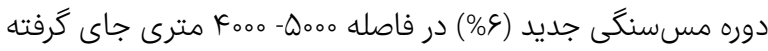

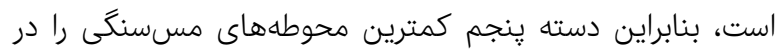

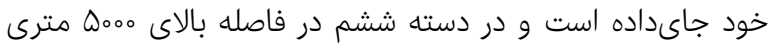

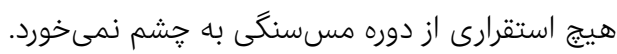

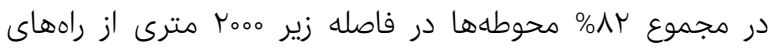

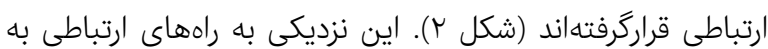

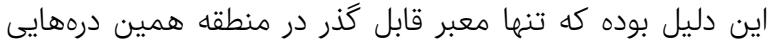

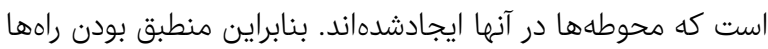

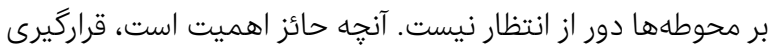
بيشتر محوطههاى يِيشازتاريخ در نزديكترين فاصله از ميسرهاى

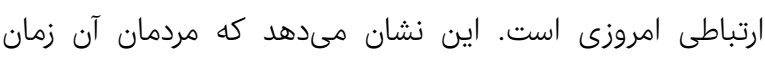
همان گونه كه امروزه نيز درجيدمان روستاهاى منطقه ديده مىشوده،

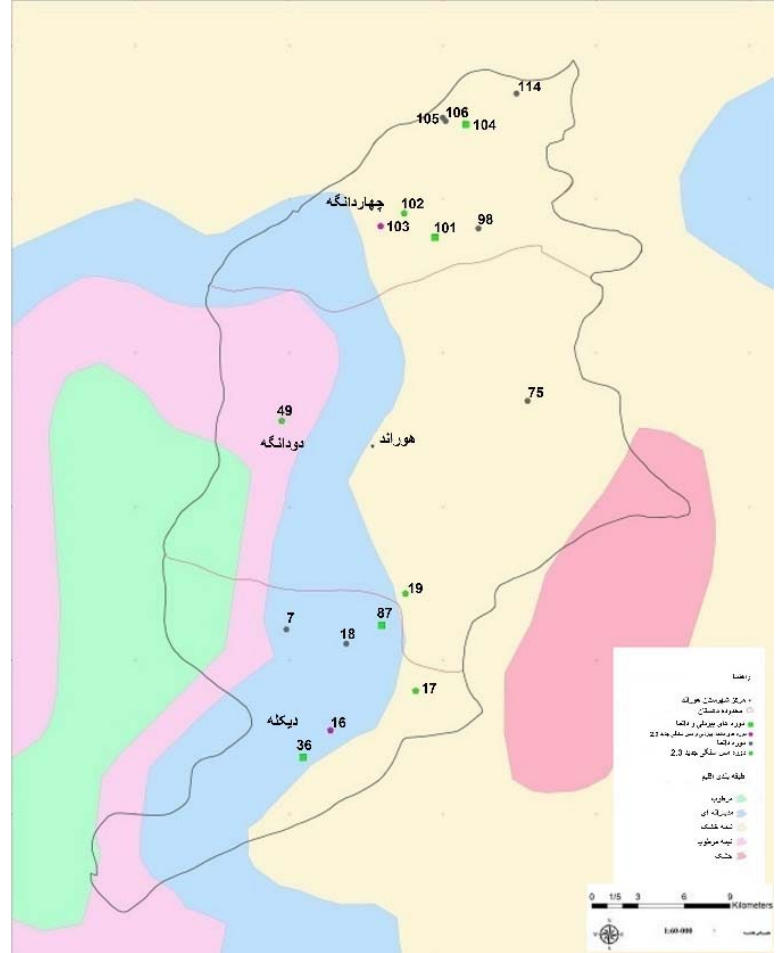

شكل r) موقعيت محوطههاى مسسنكى هوراند نسبت به منابع آبهاى دائمى و راههاى ارتباطى مولى مجنى

اين درصدها نشاندهنده همبستگى و رابطه مستقيم ميان رودخانه

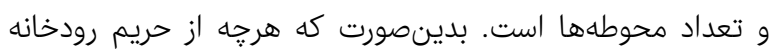

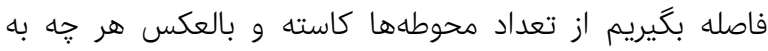
رودخانه نزديكتر شويم بر تعداد محوطهها افزوده مى إشود. در دوره مسسنكى، هو\% محوطهها در حاشيه رودخانه در فاصله كمتر از رداز

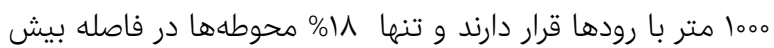

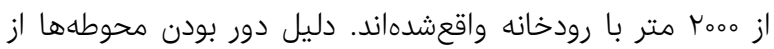

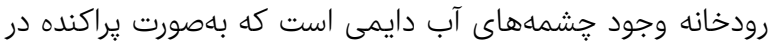

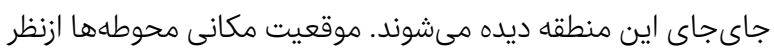

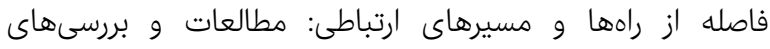

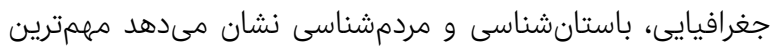

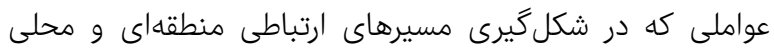

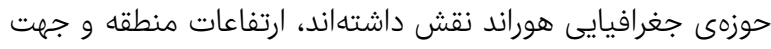

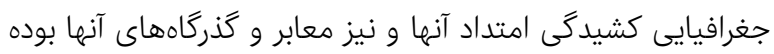

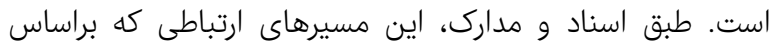

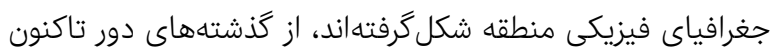

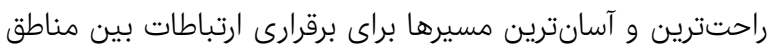

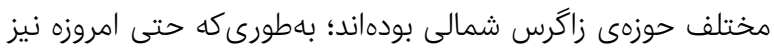

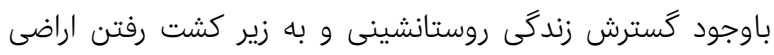

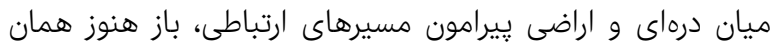

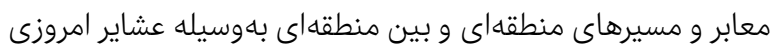

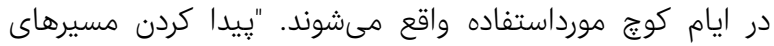

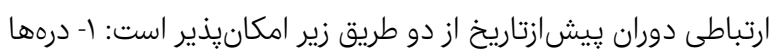

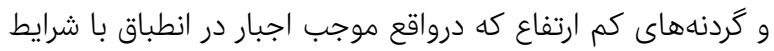




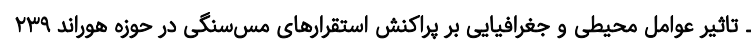

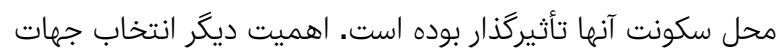

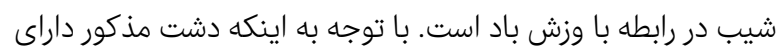

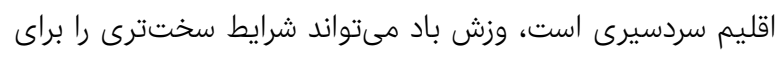

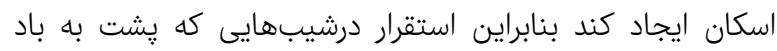

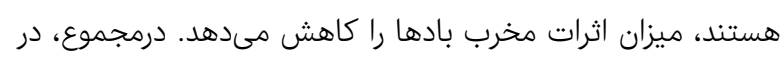

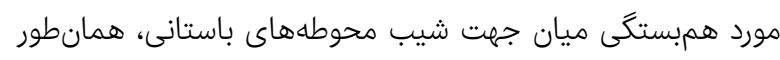

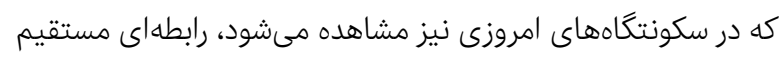

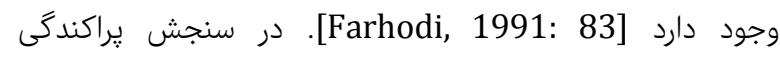
محوطههاى ييشازتاريخ حوزه هوراند، از نظر درجه شيب، محوطهها

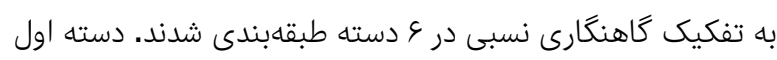

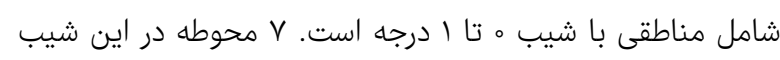

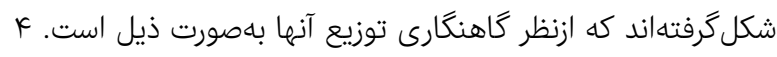

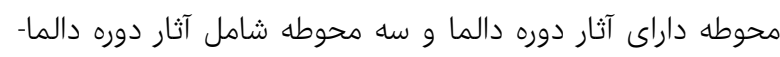

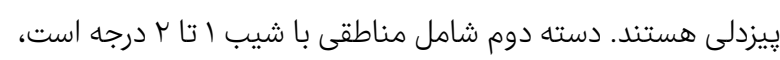

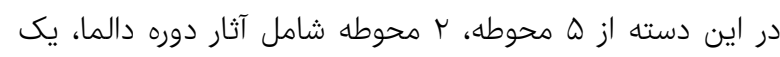

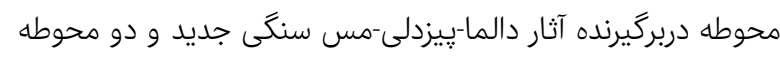

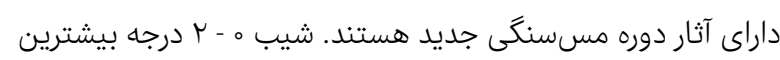
مساحت (\%) از منطقه موردبررسى را به خود اختصاص داده داده است.

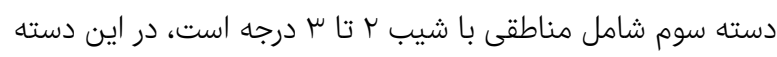

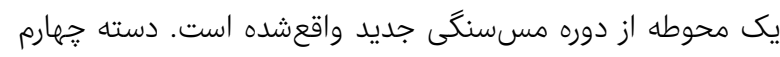

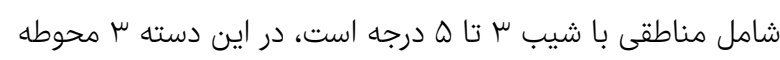

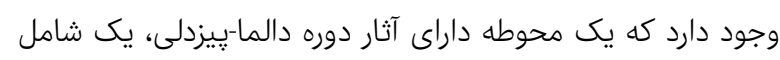

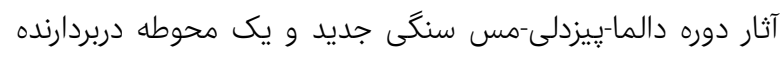

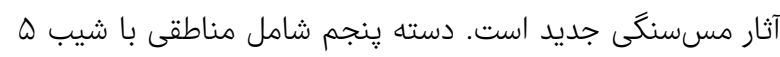

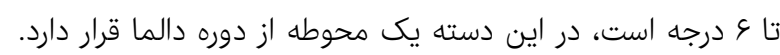

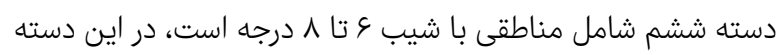

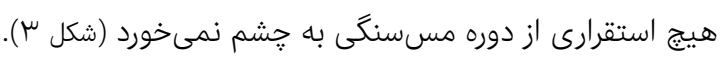

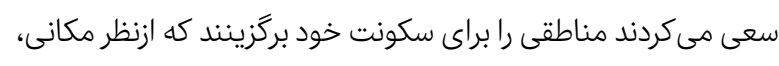

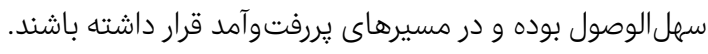

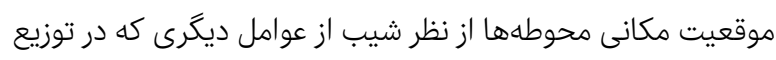

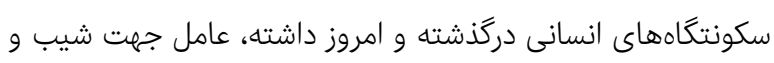

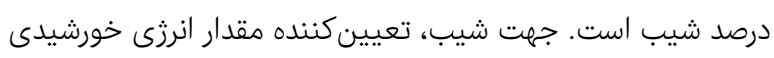

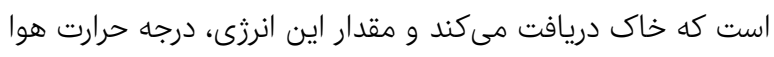

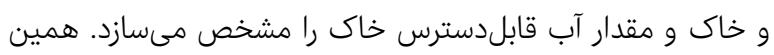

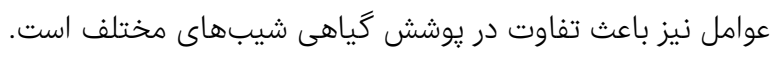

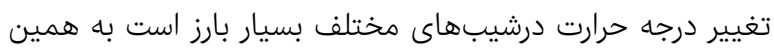

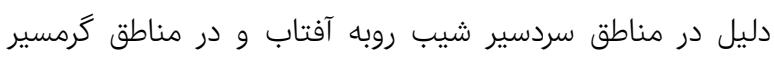

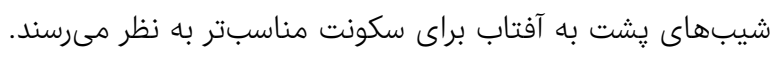

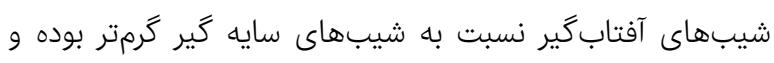

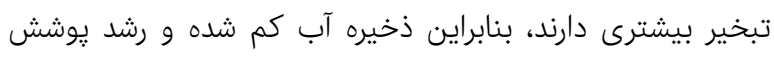

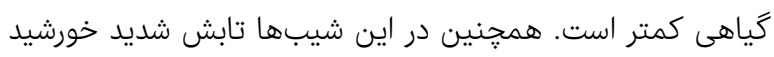

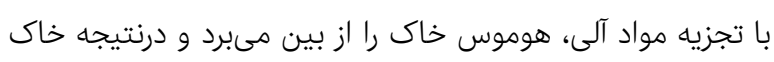

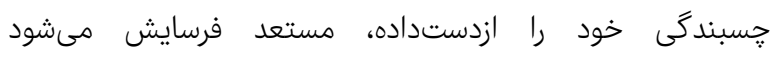

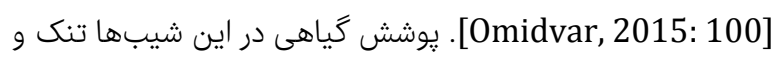
كمتر از بخشهاى سايه كير است، درحالى دكه ازنظر ايجاد

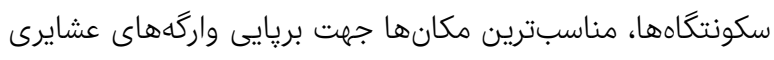

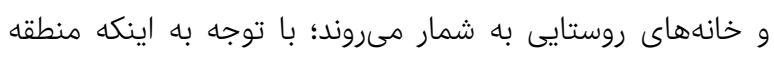

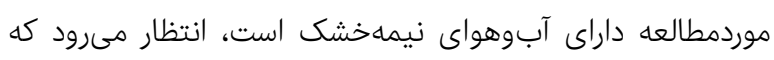

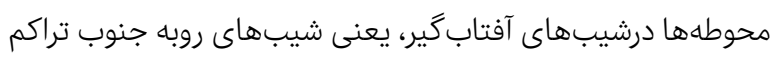

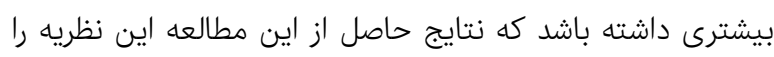

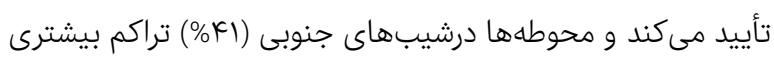

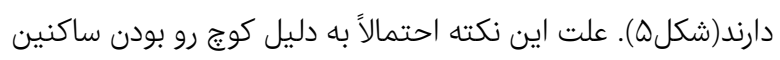

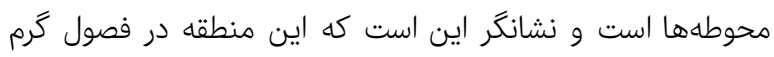

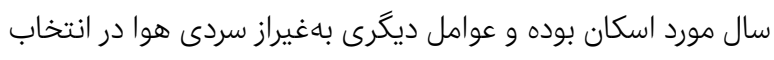

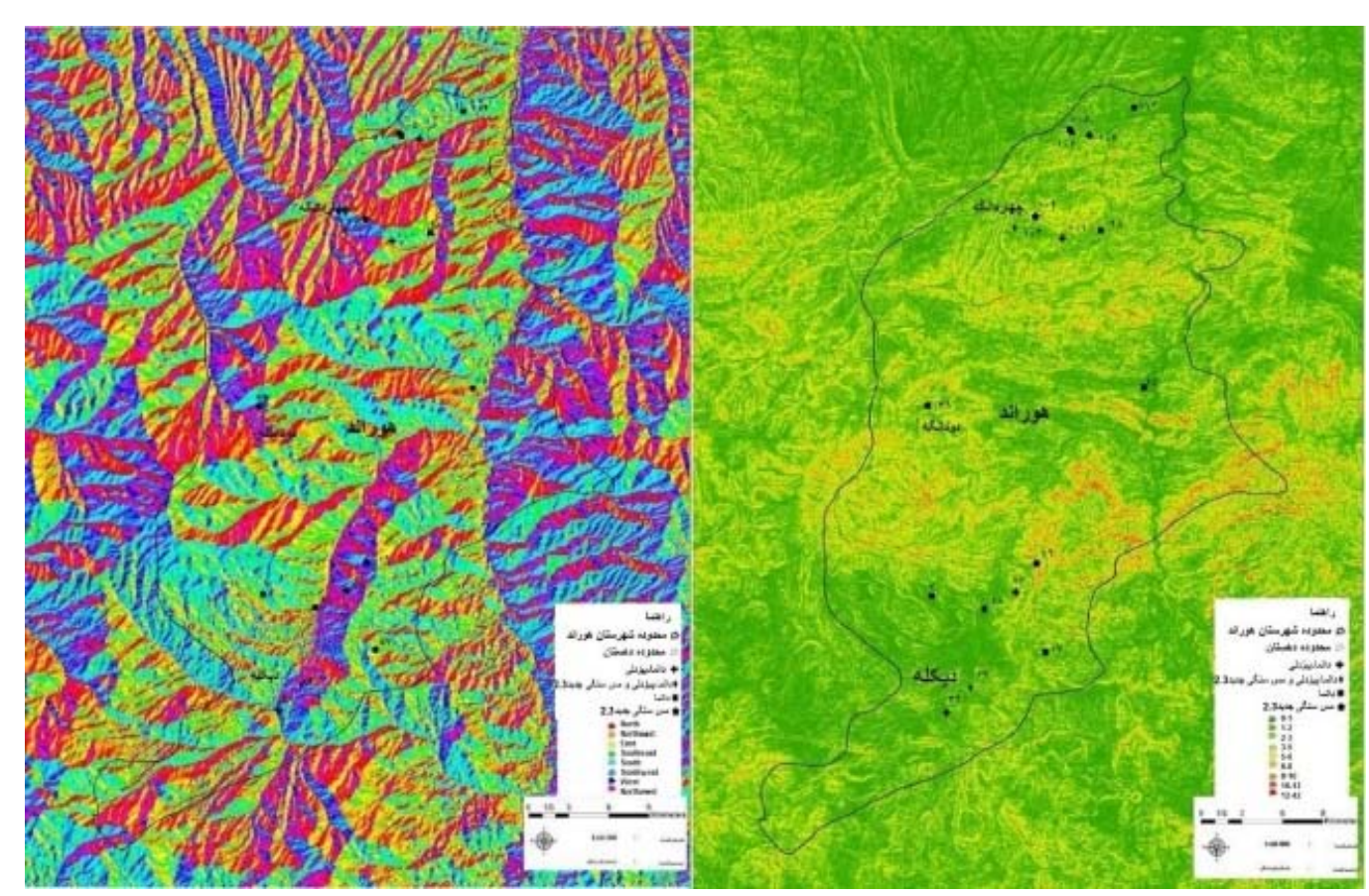

شكل س) موقعيت محوطه هاى دوره مسسنگى هوراند نسبت به جهت شيب و درصد شيب تحليل الكوهاى استقرارى محوطههاى بيش ازتاريخ شهرستان هوراند 
مىدهد. محوطههاى اين گروه همگى در ميانگين فاصله 1919

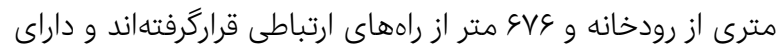

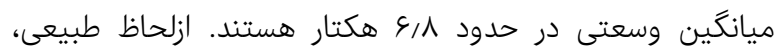

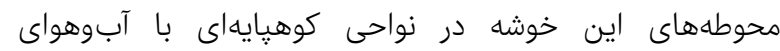

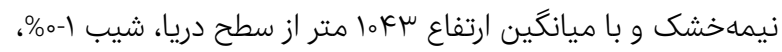

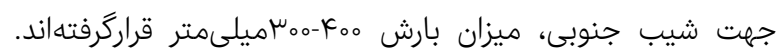

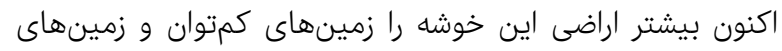

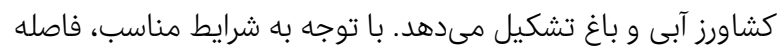

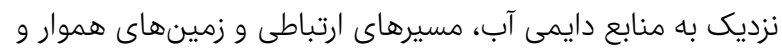

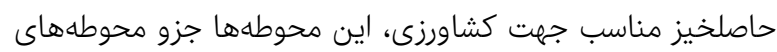

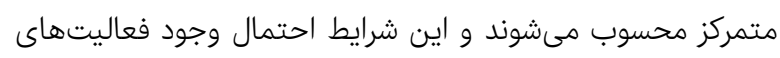

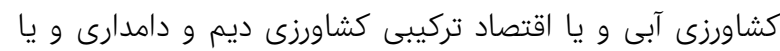

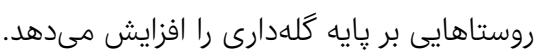

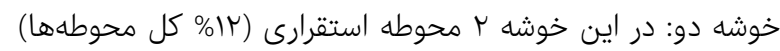

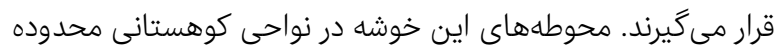

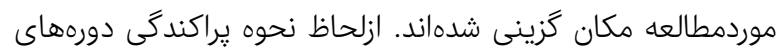

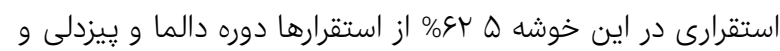

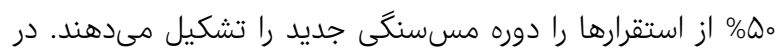

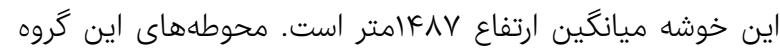

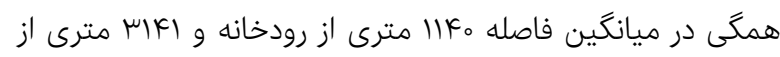

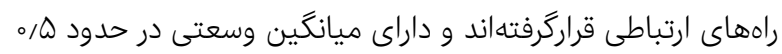

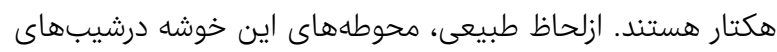
r-ا\%، جهت شيب غربى، اقليم نيمه مرطوب و با مراتع نيمه متراكم

هستند.

بحث

بين محيطزيست طبيعى يك منطقه محيطى و شرايط اقليمى آن

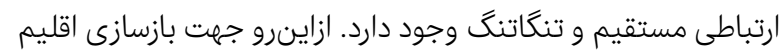

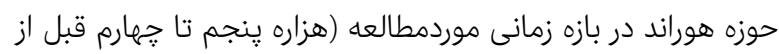

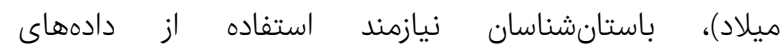

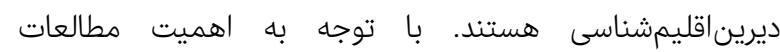

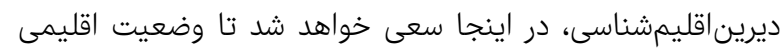

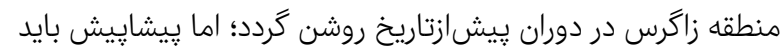
توجه داشت كه اين بازسازى به علت عدم تطابق كامل مكانى و دوران

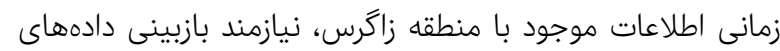

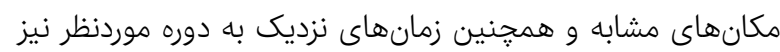

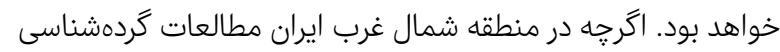

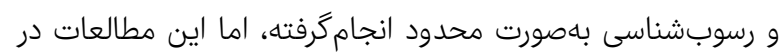

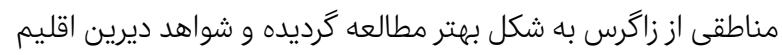

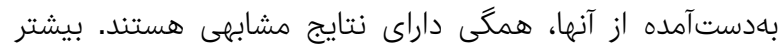

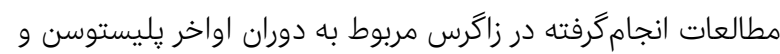
آغاز هلوسن هستند، توجه وافر به اين دورهها در مطالعات ديريناقليمشناسى به علت تلاش انسان شناسان و باستان شناسان

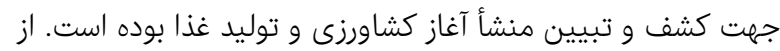

درمجموع درشيب ه تا ه درجه معمولاً دو گونه دشتهان دهاى رسوبى

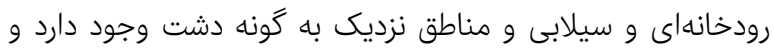

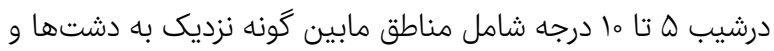

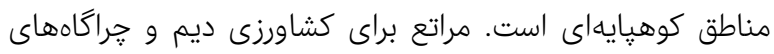

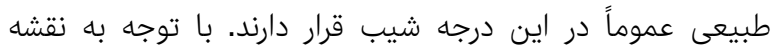

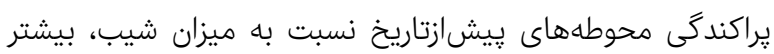

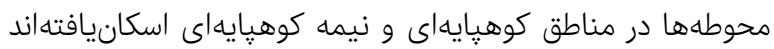

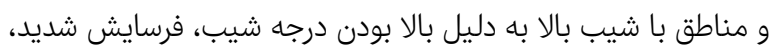

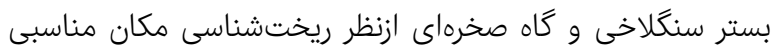
براى استقرار نيست. تحليل الخوى استقرار يكى از موضوعات مطرح در باستانشناسى نيسى

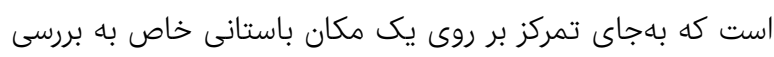

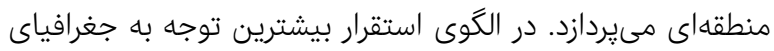

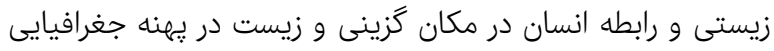

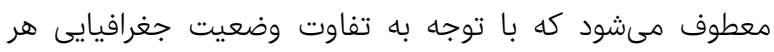

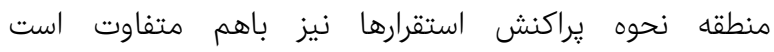

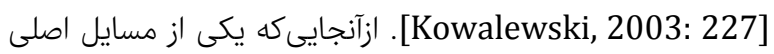

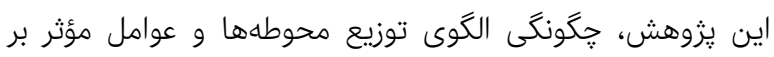

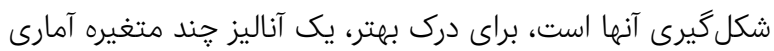

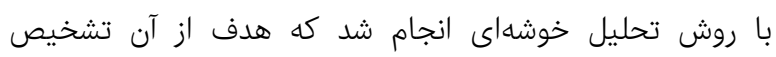
گروههايى با مشخصات همسان در مجموعه دادههاى در دسترس

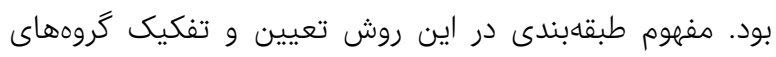

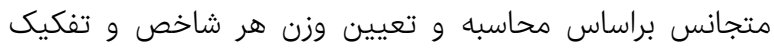
گروهها براساس محاسبه فاصله اقليدسى صورت مى مئيرد و نتيجه

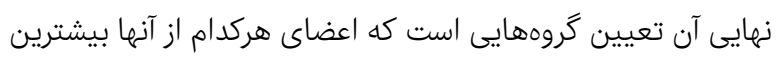

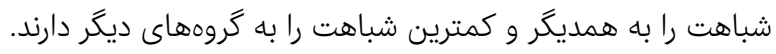
روش تعيين گروهبندى براساس نوع و اهداف تحقيق ممكن است متغير باشند و فرايندهاى عملياتى آن نيز با همديكر متفاون آندات

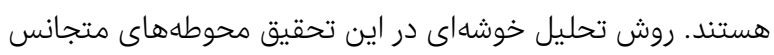

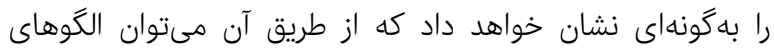

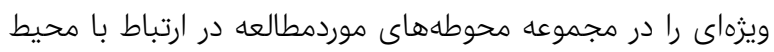

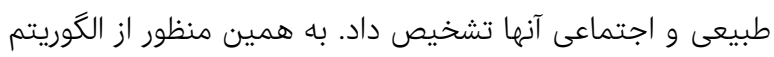

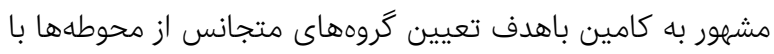

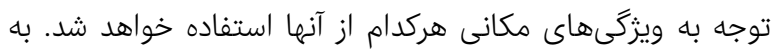

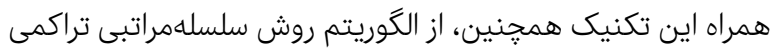

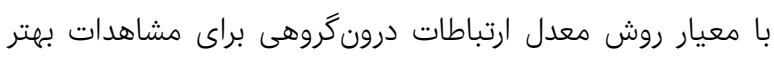

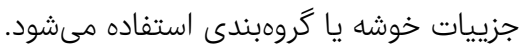

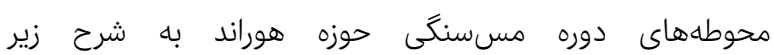
خوشهبندىشدهاند:

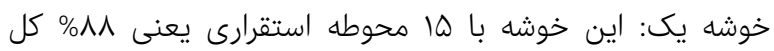

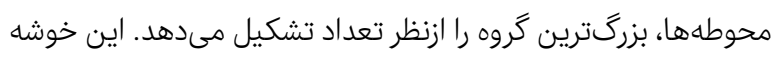
FFV

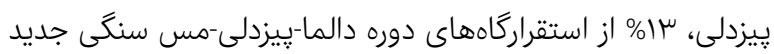

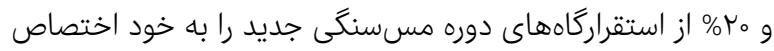




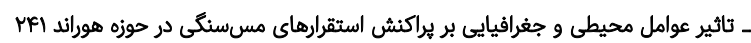

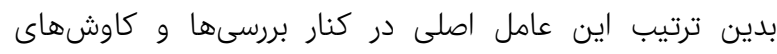

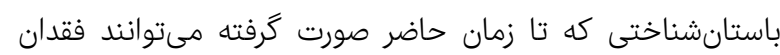

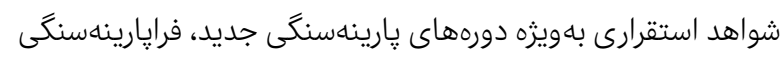

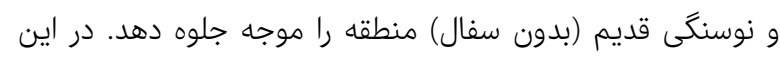

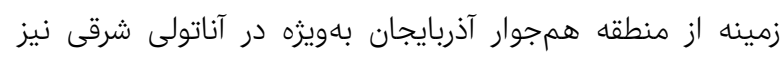

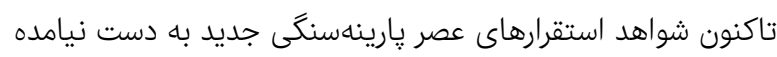

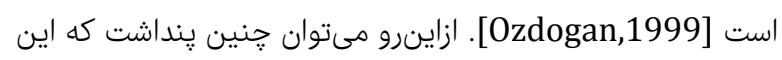

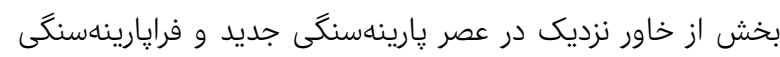

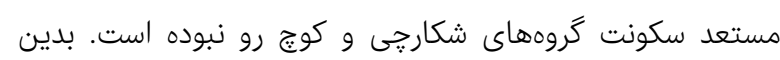

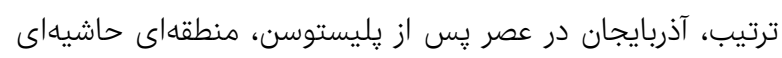

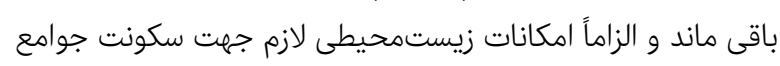

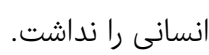

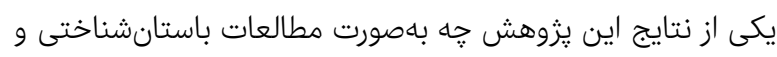

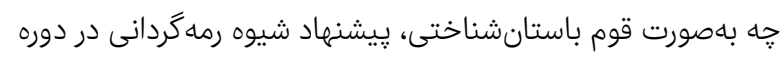

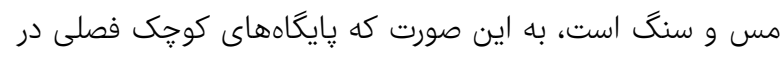

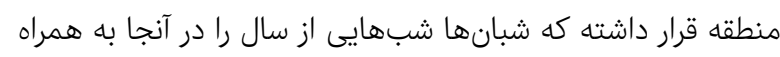

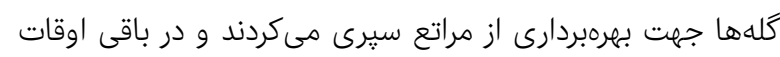

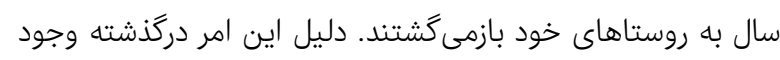

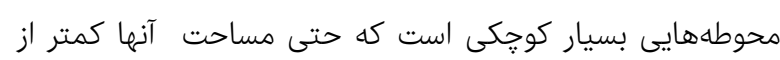

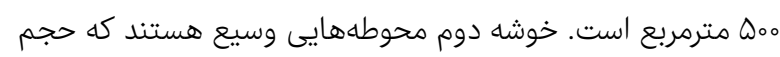

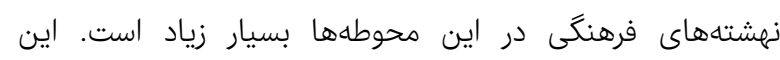

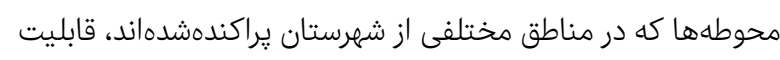

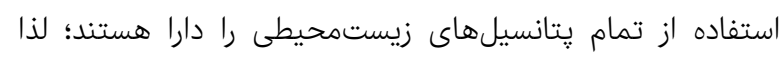

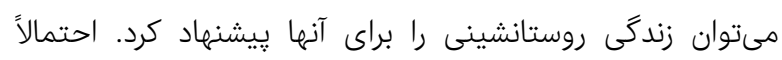

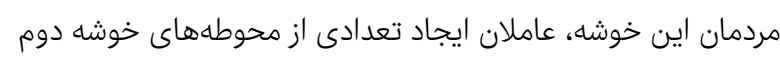

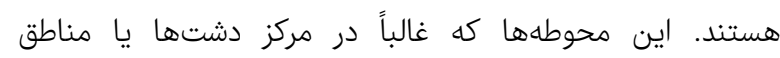

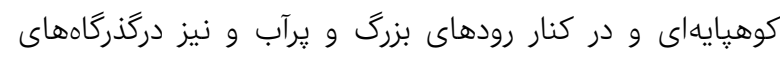

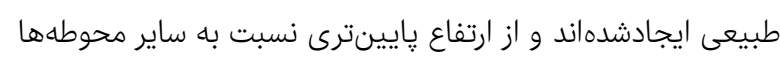

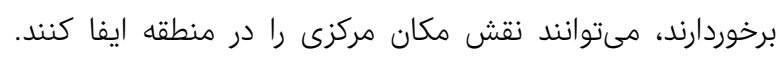

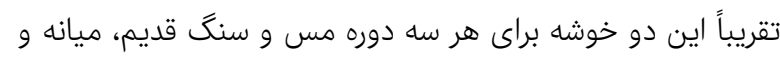

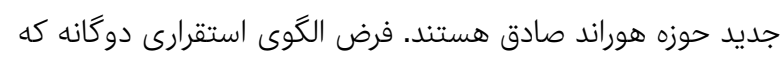

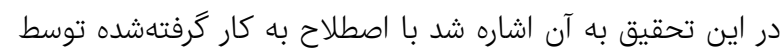

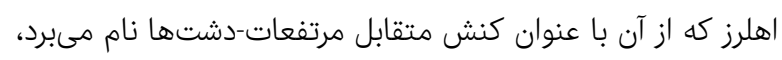

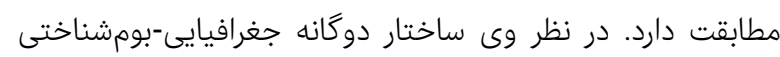

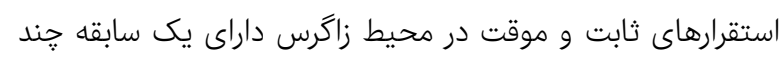

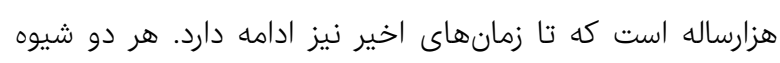

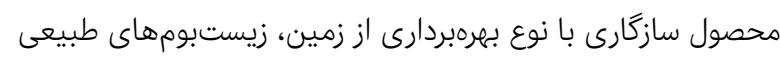

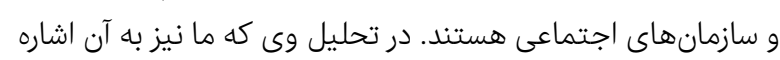

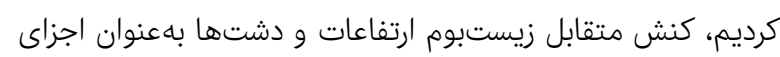

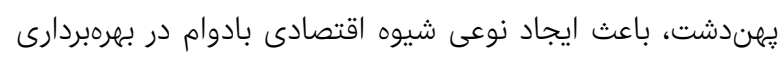

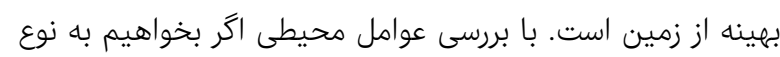

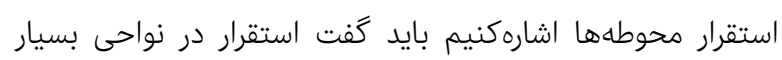

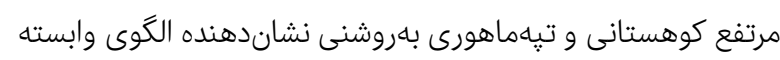
به دامدارى و كوج روى است. استقرارهاى تك دورهاى، كم وسعت،
اين مناطق مىتوان به درياجه اروميه [Djamali et al, 2008]

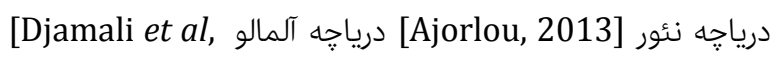

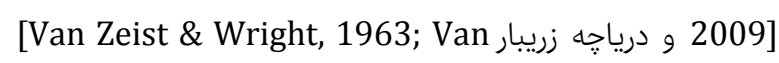
2 Zeist \& Bottema ,1991; El-Moslimany,1987]

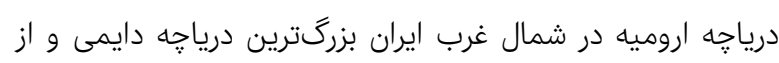

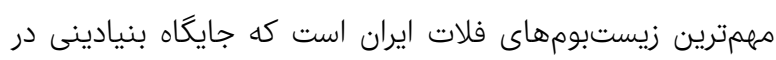

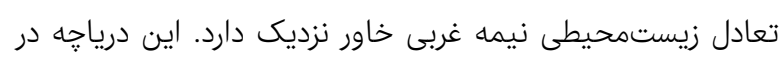

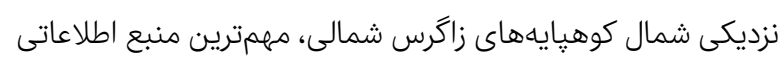

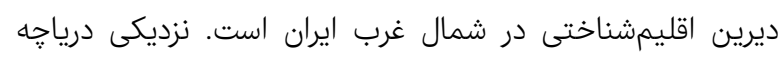

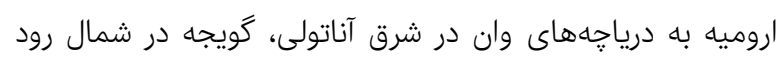

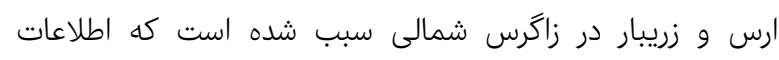

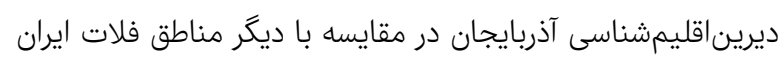

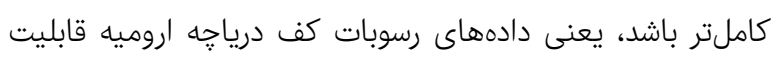

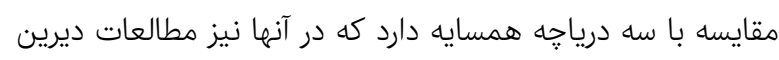

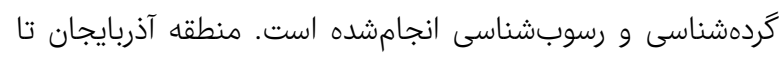

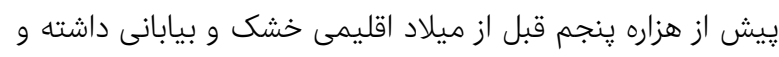

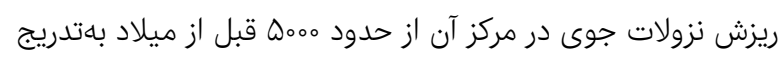

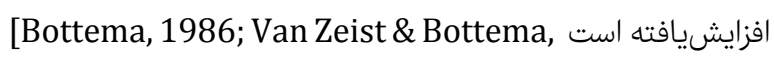
[1991. نتايج مطالعات اخير رسوبشناسى كف درياجه اروميه [Djamali et al, 2008]

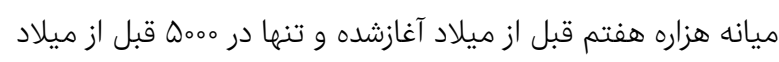

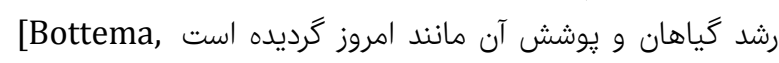

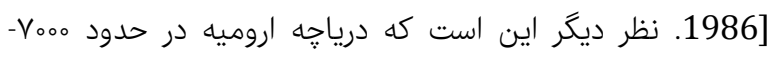

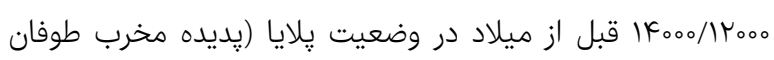

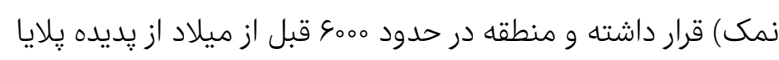

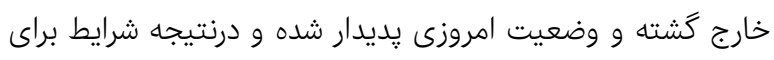

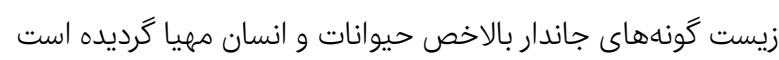

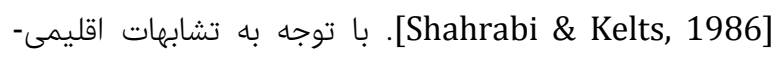

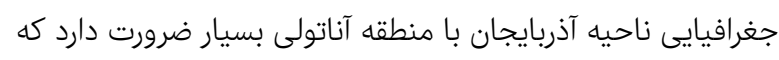

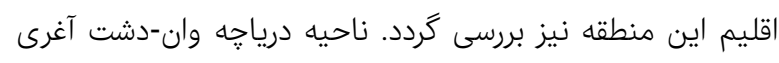

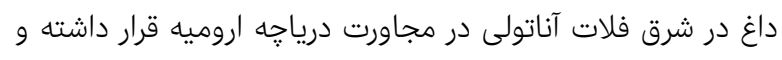

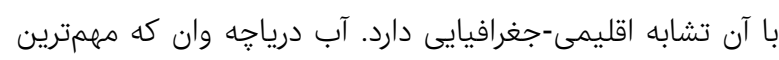

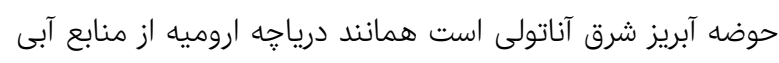

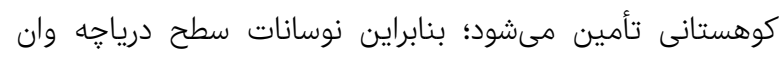

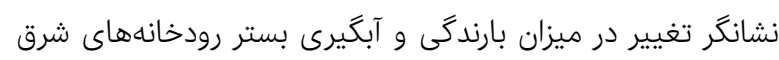

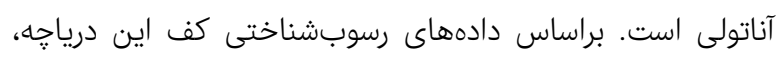

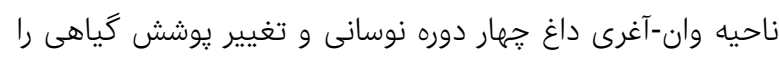

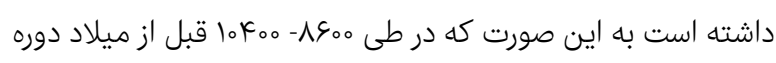

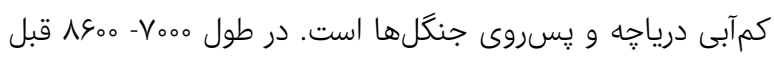

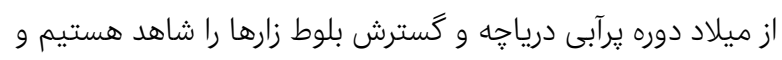

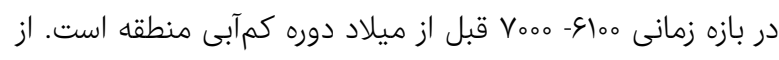

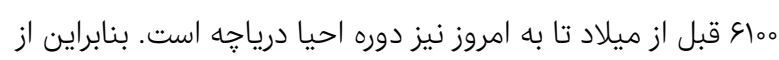

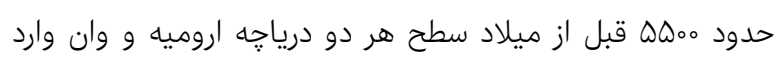

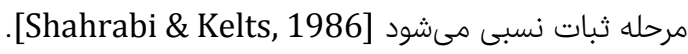


در اين تحقيق به آن اشاره شد با اصطلاح به كار گَرفتهشه توسط

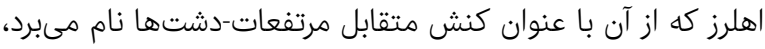

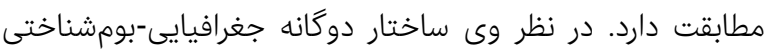

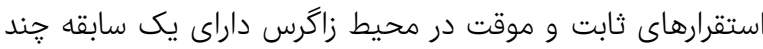

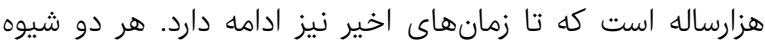

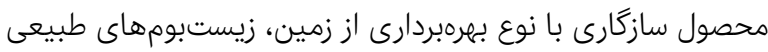

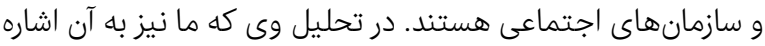

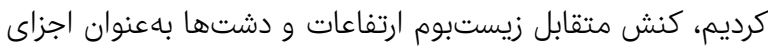

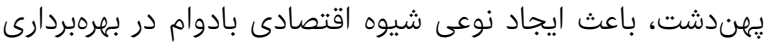

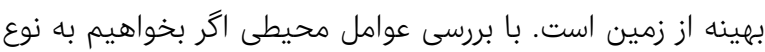

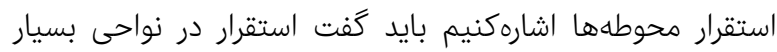

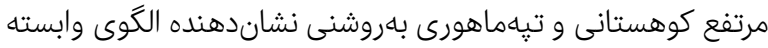
به دامدارى و كوج روى است. استقرارهاى تك دورهاى، كم وسعتى

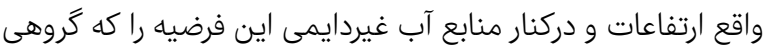

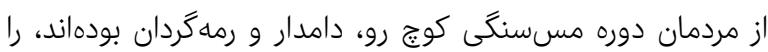

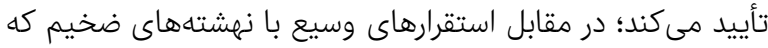

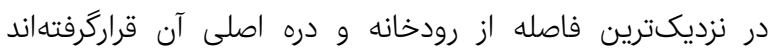

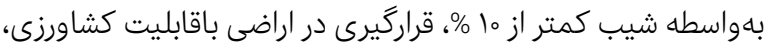

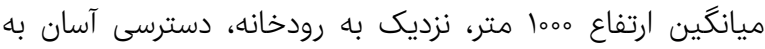

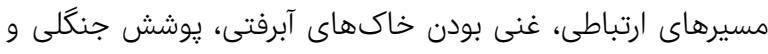

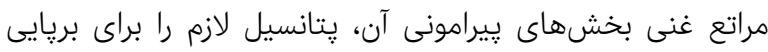

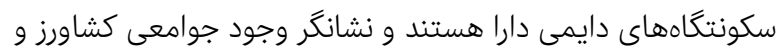
يكجانشين در حوزه هوراند هستند.

\section{نتيجه گيرى}

نحوه ״راكندگى محوطههاى باستانى در دوره مسسنكى شهرستان

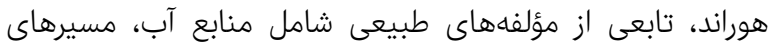

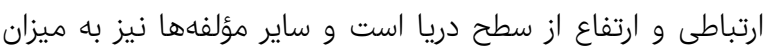

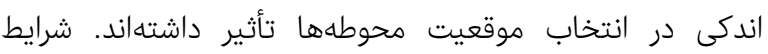

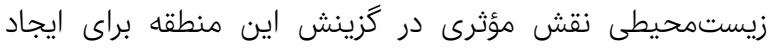

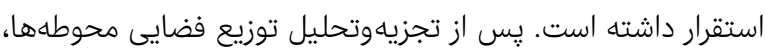

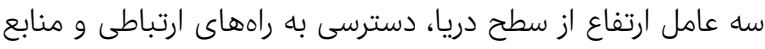

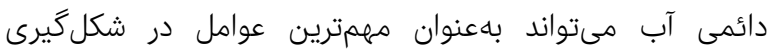

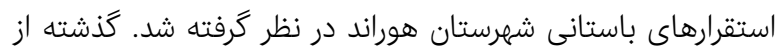

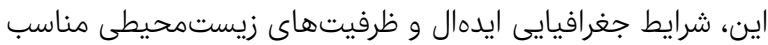

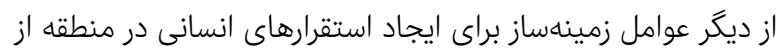

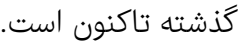

تشكر و قدردانى: موردى از سوى نويسندكان گَزارش نشده است.

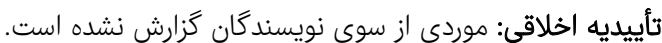

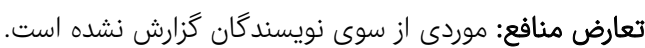

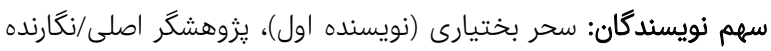

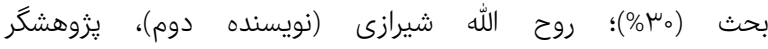

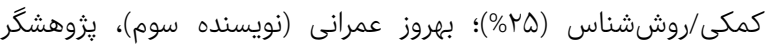

واقع ارتفاعات و دركنار منابع آب غيردايمى اين فرضيه را كه كروهى

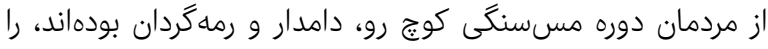

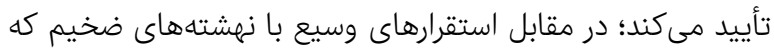

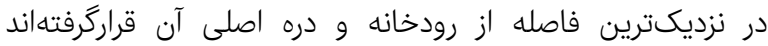

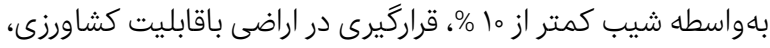

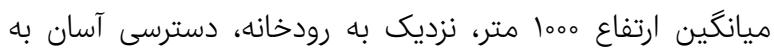

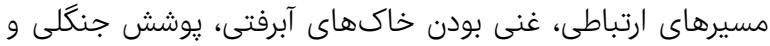

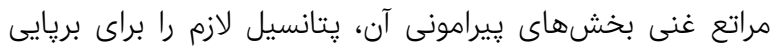

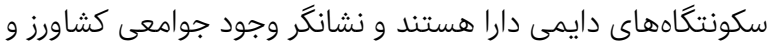
يكجانشين در حوزه هوراند هستند.

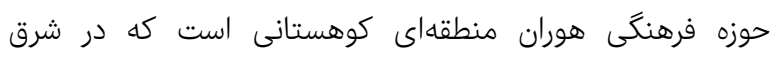

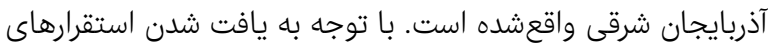

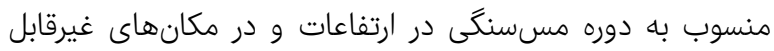

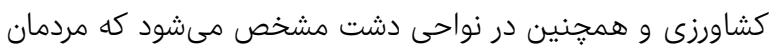

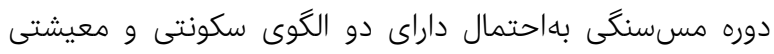

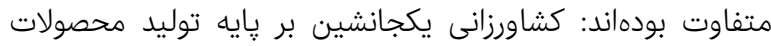

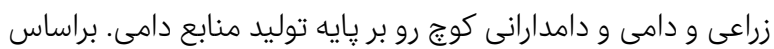

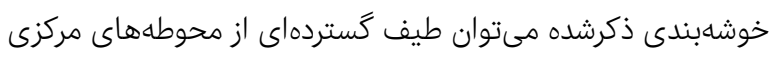

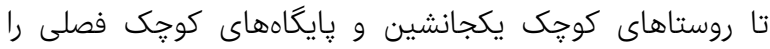
ييشنهاد كرد. خوشه اول محوطههاى كم وسعتى است كه به به ضعيف

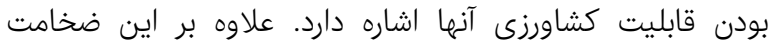

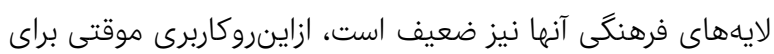
آنها يِيشنهادشده است. براين اساس شيوه كوجنشينى رمهاركردانى

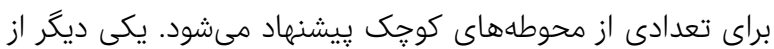

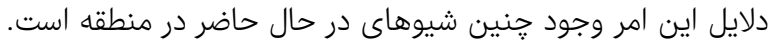

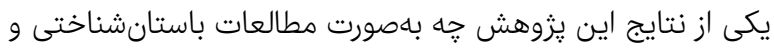
جه بهصورت قوم باستانشناختى، يِيشنهاد شيوه رمه كَردانى در دوره

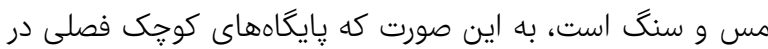

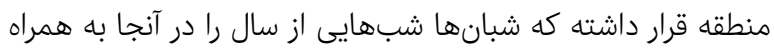
كلهها جهت بهرهبردارى از مراتع سيرى مىكردند و در باقى اودار اوقات

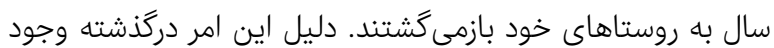

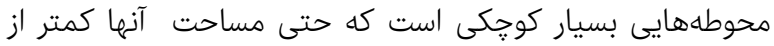

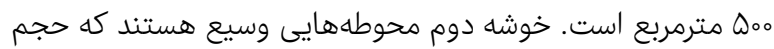

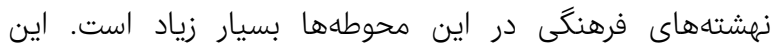

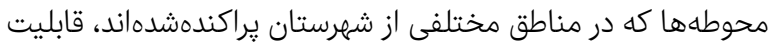

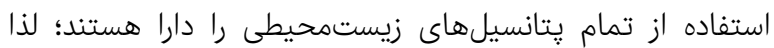

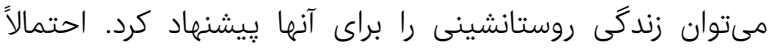

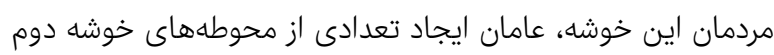

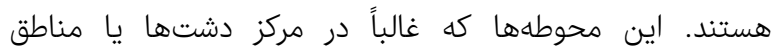

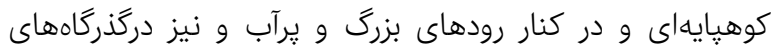

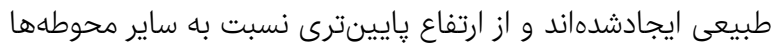

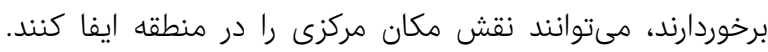

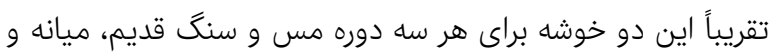
جديد حوزه هوراند صادق هستند. فرض الكوى استقرارى دوكانه كه ده 
تاثير عوامل محيطى و جغرافيايى بر براكنش استقرارهاى مسسنكى در حوزه هوراند سF

41(1):25-36

Motarjem A (2008). An investigation \& analysis of the patterns of the establishment of the Bronze age in the plains around the Alvand Mountains, Hamadan [Dissertation]. Tehran: University of Tehran. [Persian] Almasi T (2014). An investigation of the cultural changes of Kangavar plain from the Chalcolithic to the late Bronze age according to the settlement models. Pazhohesh-Ha-Ye Bastanshenasi Iran. 3(5):51-62. [Persian].

Niknami K, KhatibShahidi H, Saeedi Harsini MR (2007). Theories \& techniques of prediction modeling (estimation) of settlements \& distributions of prehistoric sites in archaeological landscapes by using GIS \& regression software, a case study: Gamasiab basin, Central Zagros. Journal of Humanities. 58(5):193-212. [Persian]

Nikzad M, Niknami K, Yadolahi S (2010). Investigating patterns of the Neolithic period in Sar-Firoozabad plain, Kermanshah. Payam-e Bastanshenas. 8(16):1-16. [Persian]

Omidvar K (2015). An introduction to soil conservation \& watershed. $3^{\text {rd }}$ Edition. Yazd: Yazd University Publication. [Persian]

Ozdogan NBM (1999). Neolithic in Turkey: The cradle of civilization: New discoveries (Ancient Anatolian civilizations series). Istanbul: Arkeoloji ve Sanat Yayinlari Publication.

Salmanpour R, Abtahi Froushani SZ (2013). Final report on the archaeological survey of Horand region. Research Institute of Cultural Heritage and Tourism. Iranian Center for Archaeological Research. Unpublished. [Persian]

Shahrabi M, Kelts K (1986). Holocene sedimentology of hypersaline lake Uremia, northwestern Iran. Palaeogeography Palaeoclimatology Palaeoecology. 54(14):105-130.

Van Zeist W, Bottema S (1991). Late Quaternary vegetation of the near east. Wiesbaden: L. Reichert Publication.

Van Zeist W, Wright HE (1963). Preliminary pollen studies at lake Zeribar, Zagros mountains, southwestern Iran. Science. 140(3562):65-67.

Velayati R, Khanali H (2017). Analyzing settlement patterns of Bronze age sites at Bostan Abad, according to regional archaeological survey. Review of European Studies. 9(3):36.

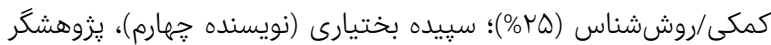

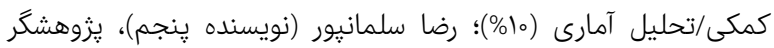

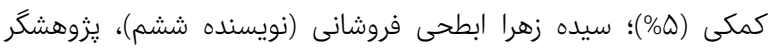

$$
\begin{aligned}
& \text { كمكى (ه\%) } \\
& \text { منابع مالى: موردى از سوى نويسندگًان گَزارش نشده است. } \\
& \text { منابع }
\end{aligned}
$$

Ajorlou B (2013). The Palaeo-climate of Iranian Plateau in the Neolithic age. Iranian Studies. 20(1):1-20. [Persian] Bahrami Nia M, Khosrowzadeh A, Esmaeili Jeludar ME (2014). Analysis of the role of environmental factors in the spatial distribution of the Neolithic and Chalcolithic sites of Ardal county, Chaharmahal Va Bakhtiari province. Archeological Studies. 5(2):21-37. [Persian]

Bottema S (1986). A late quaternary pollen diagram from Lake Urmia, northwestern Iran. Review of Palaeobotany and Palynology. 47(3-4):241-261.

Djamali M, Beaulieu JL, Shahhosseini M, Andrieu Ponel V, Ponel P, Amini A, et al (2008). A late Pleistocene long pollen record from Lake Urmia, NW Iran. Quaternary Research. 69(3):413-420.

Djamali M, Beaulieu JL, AndrieuPonel V, Berberian M, Miller N, Gandouin E, et al (2009). A late Holocene pollen record from lake Almalou in northwest Iran: Evidence for changing land use in relation to some historical events during the last 3700 years. Archaeological Science 36(7):1364-1375.

Dousti H (1994). The history and geography of Arasbaran. $1^{\text {st }}$ Edition. Tabriz: Aharar Publication. [Persian]

El-Moslimany AP (1987). The late Pleistocene climates of the lake Zeribar region (Kurdistan, western Iran) deduced from the ecology and pollen production of no arboreal vegetation. Vegetation. 72(3):131-139.

Farhoudi R (1990). Atlas of Iran slope \& its grounding results. Geographical Research. 27:75-93. [Persian]

Khamachi B (1991). Geography of east Azarbaijan. Tehran: Soroush Publication. [Persian]

Kowalewski SA (2003). Regional settlement pattern studies. Archaeological Research. 16(3):225-285.

Maziar S (2015). Settlement dynamics of the Kura-Araxes culture: An overview of the late Chalcolithic \& early Bronze age in the Khoda Afarin plain, NW Iran. Paléorient. 